UCRL-ID-130924

\title{
HIGH TEMPERATURE PROPERTIES OF ALLOYS BEING CONSIDERED FOR DESIGN OF A CONCENTRIC CANISTER LAUNCHER
}

\author{
R S. Rosen \\ Lawrence Livermore National Laboratory \\ Livermore, CA 94550 USA \\ R W. Lowry \\ Dahlgren Division \\ Naval Surface Warfare Center \\ Dahlgren, VA 22448 USA \\ and \\ M E Kassner \\ Department of Mechanical Engineering \\ Oregon State University \\ Corvallis, OR 97331 USA
}

June 1998

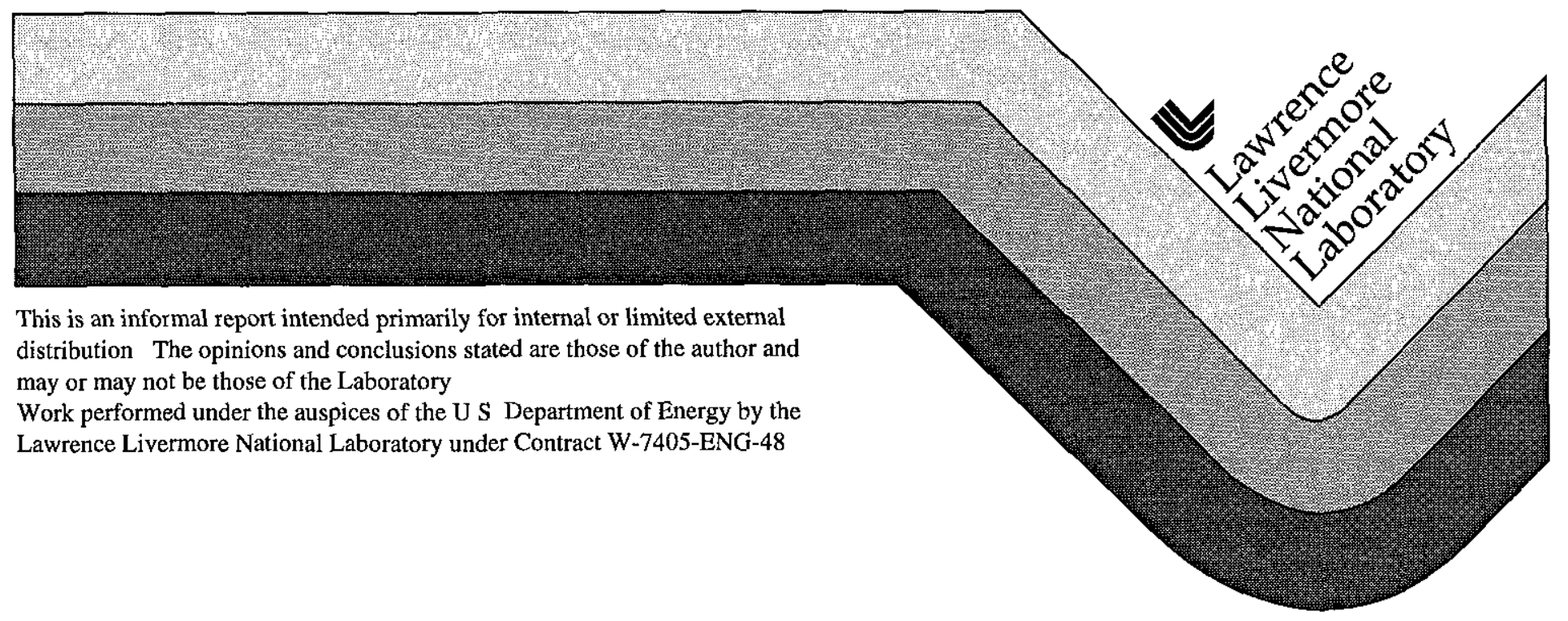




\section{DISCLAIMER}

This document was prepared as an account of work sponsored by an agency of the United States Government Neither the United States Government nor the University of California nor any of their employees, makes any warranty, express or implied, or assumes any legal liability or responsibility for the accuracy, completeness, or usefulness of any information, apparatus, product, or process disclosed, or represents that its use would not infringe privately owned rights Reference herein to any specific commercial product, process, or service by trade name, trademark, manufacturer, or otherwise, does not necessarily constitute or imply its endorsement, recommendation, or favoring by the United States Government or the University of California The views and opinions of authors expressed herein do not necessarily state or reflect those of the United States Government or the University of California, and shall not be used for advertising or product endorsement purposes

This report has been reproduced directly from the best available copy

Available to DOE and DOE contractors from the Office of Scientific and Technical Information

PO Box 62, Oak Ridge, TN 37831

Prices available from (423) 576-8401

Available to the public from the National Technical Information Service

US Department of Commerce 5285 Port Royal Rd,

Springfield, VA 22161 
Public reporting burden for this collection of information is estimated to average 1 hour per response, including the time for reviewing instructions, search existing data sources, gathering and maintaining the data needed, and completing and reviewing the collection of intormation Send comments regarding this burden or any other aspect of this collection of information, including suggestions for reducing this burden, to Washington Heedquarters Services Directorate for information Operations and Reports, 1215 Jefferson Davis Highway, Suite 1204, Arlington, VA 222024302 and to the Office of Management and Budget Paperwork Reduction Project (0704-0188), Washington. DC 20503

\begin{tabular}{|l|c|c|}
\hline 1 AGENCY USE ONLY (Leave blank) & $\begin{array}{c}\text { 2. REPORT DATE } \\
\text { June } 1998\end{array}$ & $\begin{array}{c}\text { 3. REPOR } \\
\text { Final }\end{array}$ \\
\hline
\end{tabular}

\section{TITLE AND SUBTITLE}

5 FUNDING NUMBERS

High Temperature Properties of Alloys Being Considered for Design of a Concentric Canister Launcher

6 AUTHOR(s)

Robert S Rosen, Robert W Lowry, Michael E Kassner

7 PERFORMING ORGANIZATION NAME(S) AND ADDRESS(ES)

Commander

Naval Surface Warfare Center

Dahlgren Division (Code G704)

17320 Dahlgren Road

Dahlgren, VA 22448-5100
B PERFORMING ORGANIZATION REPORT NUMBER

NSWCDD/TR $-98 / 72$

\section{SPONSORING/MONITORING AGENCY NAME(S) AND ADDRESS(ES)}

10. SPONSORING/MONITORING AGENCY REPORT NUMBER

11 SUPPLEMENTARY NOTES

12a. DISTRIBUTION/AVALABILITY STATEMENT

Approved for public release, distribution is unlimited 12b DISTRIBUTION CODE

\section{ABSTRACT (Maximum 200 words)}

This report describes a study to determine the high temperature mechanical properties of several titanium alloys and to compare them with properties of AISI $316 \mathrm{~L}$ stainless steel and ASTM A387 structural steel The steel materials are less costly to procure but exhibit good resistance to corrosion in seawater environments Six titanium alloys were evaluated as candidate materials for use in a Concentric Canister Launcher (CCL) Each titanium alloy was tested at three temperatures $\left(68^{\circ} \mathrm{F}, 2000^{\circ} \mathrm{F}\right.$, and $2400^{\circ} \mathrm{F}$ ) Strain-rate change tests were used to determine the strain rate sensitivity of the alloys at each test temperature Optical metallography was performed on two of the alloys to determine the relationship between test temperature and microstructure (presence of second phase precipitates, grain size) Complete test results are included, along with figures and tables of test data

\section{SUBJECT TERMS}

Concentric Canister Launcher (CCL), titanium, tensile tests, strain rate sensitivity, optical metallography
15. NUMBER OF PAGES

33

16. PRICE CODE

\begin{tabular}{|l|l|l}
\hline $17 \begin{array}{l}\text { SECURITY CLASSIFICATION } \\
\text { OF REPORTS }\end{array}$ & $\begin{array}{l}18 \text { SECURITY CLASSIFICATION } \\
\text { OF THIS PAGE } \\
\text { UNCLASSIFIED }\end{array}$ & $\begin{array}{l}19 \\
\text { UNCLASSIFIED } \\
\text { OF ABSTRACT } \\
\text { UNCLASICATION }\end{array}$
\end{tabular}

20 LIMITATION OF ABSTAACT

$\leqslant$




\section{FOREWORD}

This report describes the results of a study undertaken to determine the high temperature mechanical properties of several alloys being considered for design of a concentric canister launcher (CCL) The work was carried out in support of Naval Surface Warfare Center, Dahlgren Division (NSWCDD) as part of one author's (Rosen's) Naval Reserve assignment as an Engineering Duty Officer with the Naval Sea Systems Command (SEA 03K) in Arlington, Virginia R. S. Rosen is a member of Lawrence Livermore National Laboratory, Livermore, California R. W Lowry is the CCL project engineer for NSWCDD Code G72. M E Kassner is the Northwest Aluminum Professor of Mechanical Engineering and Director of the Graduate Program in Materials Science at Oregon State University, Corvallis, Oregon The titanium alloy tensile tests were performed at Oregon State University and were funded by NSWCDD

The authors wish to thank Steve Paddon and Troy Hayes of Oregon State University for their assistance in performing the titanium alloy tensile tests

J J. Yagla and G C. Blount of the Combat Systems Safety and Engineering Division of the Weapons System Department have reviewed this report

Approved by.

JOHNNY WALTERS, Deputy Head

Weapons Systems Department 


\section{CONTENTS}

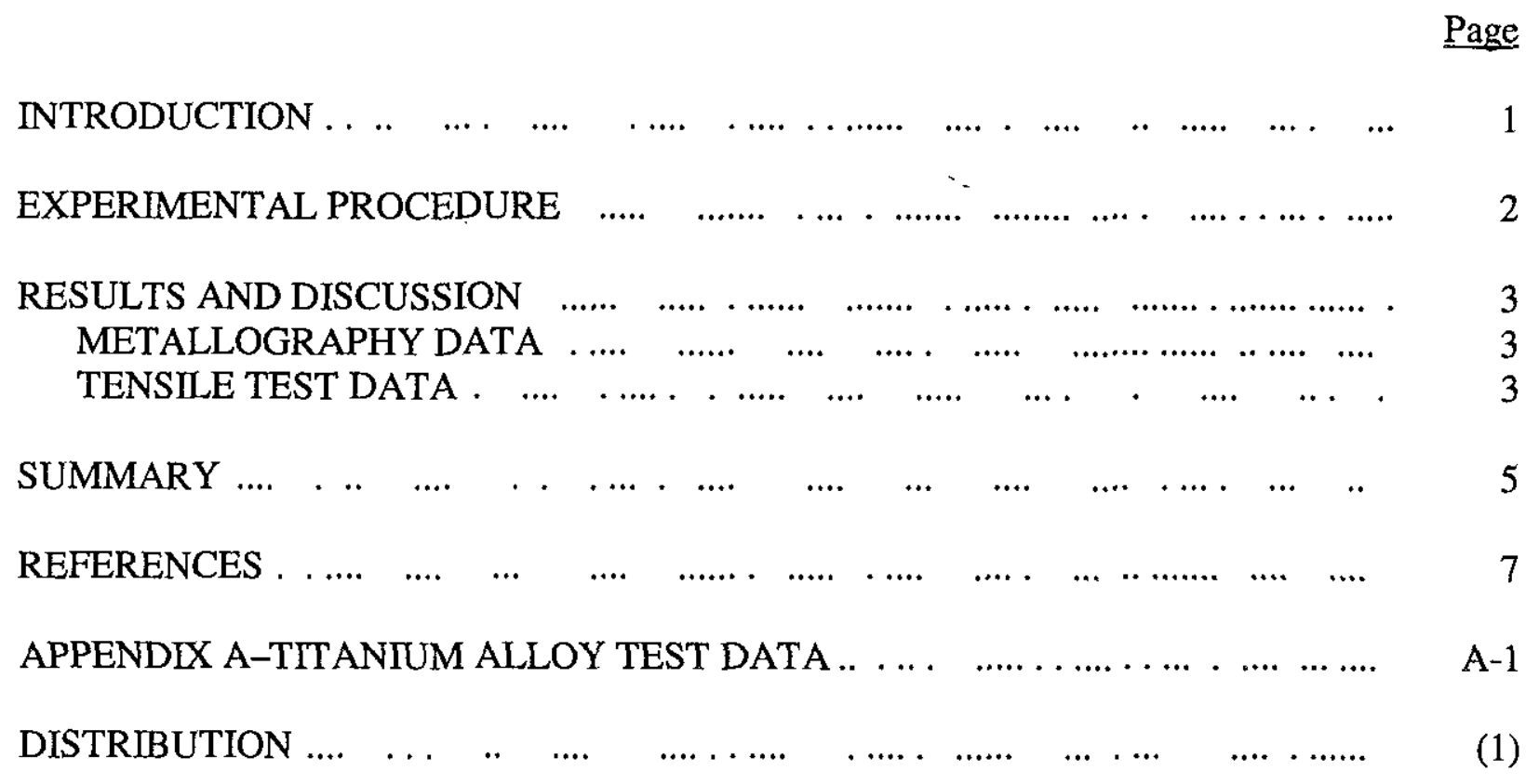




\section{ILLUSTRATIONS}

Figure

Page

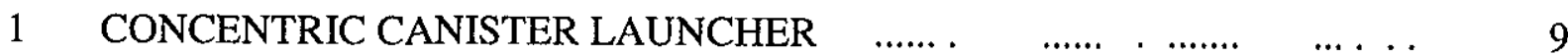

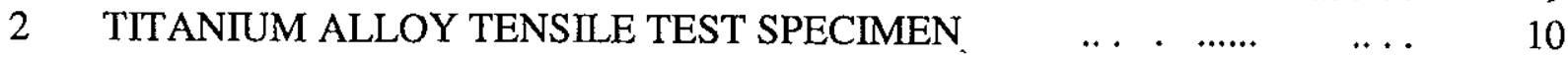

3 INCREASE IN GRAIN SIZE OF Ti-15-3 WITH SOAK TIME AT

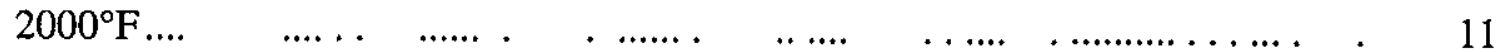

4a VARIATION IN YIELD STRESS OF TITANIUM ALLOYS WITH TEMPERATURE ......... 12

$4 \mathrm{~b}$ YIELD STRESS OF TITANIUM ALLOYS AT VERY HIGH TEMPERATURES

5 VARIATION IN YIELD STRESS OF Ti-6-4 WITH STRAIN RATE... . ...

6a VARIATION IN STRAIN RATE SENSITIVITY OF Ti-6-4 WITH STRAIN RATE

$6 \mathrm{~b}$ VARIATION IN STRAIN RATE SENSITIVITY OF Ti-6-4 WITH TEMPERATURE

7 VARIATION IN YIELD STRESS OF 316 STAINLESS STEEL WITH

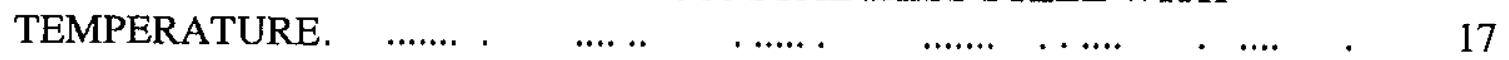

8 VARIATION IN YIELD STRESS OF TITANIUM ALLOYS, 316 STAINLESS STEEL, AND A387 STEEL WITH TEMPERATURE $\quad \ldots . . . \quad \ldots \quad . \quad 18$

\section{TABLES}

Table

1 TTTANIUM ALLOY DATA FROM THIS STUDY AND COMPILED FROM THE LITERATURE.... .

2 TYPE 316 STAINLESS STEEL AND A387 STEEL DATA COMPILED FROM THE LITERATURE 
NSWCDD/TR-98/72

\section{INTRODUCTION}

The Office of Naval Research (ONR) has undertaken a program to develop a new Vertical Launching System (VLS) for future generation ships, such as the DD-21 Destroyer The Naval Sea Systems Command Combat Weapons Program (NAVSEA 03K1) and Naval Surface Warfare Center Dahlgren Division (NSWCDD) are working jointly with industry and universities to develop one such launcher design, the Concentric Canister Launcher (CCL)

The CCL provides two significant advances over the current Mk 41 VLS First, it is designed with a self-contained gas management system that eliminates the need to overhaul ship structures below deck level. Second, the CCL has its launch electronics distributed individually in each canister enhancing the reliability of the overall system The launcher system would consist of an array of perhaps 32 CCLs, each carrying one missile, arranged in a modular rack which could be moved from ship to ship. The CCL design is adaptable to fire a variety of missiles in the Navy inventory. Remanufacturing and reloading of canisters after firings is one design alternative being considered.

The basic CCL design consists of a tube made of two concentric cylinders joined by sets of dual longerons; one end is open, the other is sealed with a hemispherical end cup, or "hemihead" (see Figure 1). During firing, the missile exhaust gas is turned 180 degrees by the hemihead and flows through the annular space between inner and outer cylinders Ablative material would most likely need to be applied to the hemihead to protect the surface from erosion/corrosion at the extremely high temperatures produced by the exhaust gases during a "fly-out" of the missile. Depending on the missile utilized and the particular service environment (e.g , a restrained firing whereby the missile fails to exit the canister), maximum temperatures within the cylinder material have been calculated to exceed $2000^{\circ} \mathrm{F}\left(1093^{\circ} \mathrm{C}\right)$.

The extreme temperature combined with modest pressures from the hot gases in the annular region results in stresses of sufficient magnitude to consider a high temperature alloy for the CCL Titanium is a material to be considered for this application because of its high specific strength and high temperature oxidation resistance combined with its outstanding resistance to corrosion in seawater. Therefore, the objective of this study is to determine the high temperature mechanical properties of several titanium alloys and to compare them with properties of AISI $316 \mathrm{~L}$ stainless steel and ASTM A387 structural steel, materials less costly to procure than titanium but nonetheless exhibiting good resistance to corrosion in seawater environments. 


\section{EXPERIMENTAL PROCEDURE}

The following titanium alloys were evaluated as candidates materials in this study (nominal compositions given) (1) TIMETAL 21S (Ti-15Mo-3Nb-3Al-2Si); (2) Ti-15-3 (Ti15V-3Al-3Cr-3Sn); (3) Ti-13-11-3 (Ti-13V-11Cr-3Al), (4) Beta C (Ti-8V-3Al-6Cr-4Mo-4Zr); (5) Beta III (Ti-11 5Mo-6Zr-4.5-Sn); and (6) Ti-6-4 (Ti-6Al-4V). The first five materials are beta stabilized at room temperature, exhibiting high strengths and good cold formability; Ti-6-4 is a two-phase alpha+beta structure at room temperature Specimens to be tested were machined from sheet material supplied from the following sources' United Defense, Fridley, Minnesota (TIMETAL 21S), Titanium Metals Corporation (TIMET), Denver, Colorado (Ti-15-3), Crucible Materials, Pittsburgh, Pennsylvania, (Ti-13-11-3 and Beta III); RMI Titanium, Niles, Ohio (Beta C); and Metals Unlimited, Inc , Deer Park, New York (Ti-6-4)

The test specimen geometry consisted of a 2-inch-long tensile specimen having a rectangular cross-section with gage dimensions of 0.400 inches in length, 0188 inches in width, and 0.600 inches in depth (see Figure 2) Machining tolerances of the finished specimen were \pm 0001 inches in all dimensions. Specimens were cut in the plane of the sheet material and surface finished on a milling machine. Afterwards, the specimens were encapsulated in a quartz chamber purged with argon prior to heat treatment All of the specimen materials were solution treated and aged for maximum room temperature tensile strength properties as suggested by ASM data (Reference 1); an additional specimen of TIMETAL 21S was solution treated and aged to achieve maximum high temperature tensile strength as recommended by TIMET (Reference 2) (see Table A-1 in Appendix A) This process of quenching the "beta" alloys from the beta phase $\left(815^{\circ} \mathrm{C}\right)$ and aging at approximately $540^{\circ}$ to $480^{\circ} \mathrm{C}$ for 4 to 72 hours results in finely dispersed alpha precipitates in the beta structure.

Tensile tests were performed on a servohydraulic Instron model 8521 testing machine, capable of real-time computerized data acquisition The specimens were held with a friction-type TZM molybdenum alloy (Mo-0 5Ti-0 1Zr-0.02W) grip and a tungsten pin Instron universal joints were used on each side of the TZM grip to eliminate any bending moments applied to the specimen from the loading fixture

Each of the titanium alloys was tested at three temperatures $68^{\circ} \mathrm{F}\left(20^{\circ} \mathrm{C}\right), 2000^{\circ} \mathrm{F}$ $\left(1093^{\circ} \mathrm{C}\right)$, and $2400^{\circ} \mathrm{F}\left(1316^{\circ} \mathrm{C}\right)$ The (elevated) test temperatures of the specimens were held to within $\pm 10^{\circ} \mathrm{C}$ at the yield stress and ultimate tensile strength, and within $\pm 30^{\circ} \mathrm{C}$ at the termination of the test (typically, after about 30 percent elongation). For tests performed at $1093^{\circ} \mathrm{C}$ and $1316^{\circ} \mathrm{C}, 30$ to 3.5 minutes was required to heat the specimens to test temperature. Temperatures were measured on the specimen surface using Pt/Pt-13Rh type thermocouples The temperature gradient from the surface to the center of the specimen was calculated to be less than $1^{\circ} \mathrm{C}$. This small gradient is primarily due to the small size and flat shape of the specimen Uniform temperatures (within $5^{\circ} \mathrm{C}$ ) were measured across the gage length from shoulder to shoulder

Strain-rate change tests were used to determine the strain rate sensitivity of the alloys at: each test temperature The strain rate sensitivity, $m=\mathrm{d}[\log (\sigma)] / \mathrm{d}[\log (\mathrm{d} \varepsilon / \mathrm{d} t)]$, was determined at a constant structure (i e , a particular microstructure) by measuring the change in the yield stress, 
$\sigma$ with an instantaneous change in the applied strain rate, $\mathrm{d} \varepsilon / \mathrm{d} t$ The changes in strain rate were $\mathrm{d} \varepsilon / \mathrm{d} t=10^{-4} \mathrm{~s}^{-1}$ to $10^{-2} \mathrm{~s}^{-1}$ at $20^{\circ} \mathrm{C}$, and $\mathrm{d} \varepsilon / \mathrm{d} t=10^{-3} \mathrm{~s}^{-1}$ to $10^{-2} \mathrm{~s}^{-1}$ at $1093^{\circ} \mathrm{C}$ and $1316^{\circ} \mathrm{C}$ tests. High purity (Grade 5) argon was used to purge a quartz chamber surrounding the titanium specimens during the high temperature tests This ensured that the test results would not be influenced by high temperature oxide embrittlement of the titanium alloys (Reference 3) Percent elongation and reduction in area were measured directly from the specimen at the conclusion of the tensile tests Percent elongation was also measured from the crosshead displacement of the Instron machine to a resolution of 00001 inch. Stress-strain relationships were determined by subtracting the Instron machine system compliance from the load-elongation data as measured from the crosshead displacement. Yield stresses and ultimate tensile strengths were reported as engineering values (based on initial cross-sectional area) Yield stresses were measured at a strain (plastic) of $\varepsilon_{p}=0002$ using the 0.2 percent strain offset method. Tensile test data are given in Appendix A, Table A-1 $\left(68^{\circ} \mathrm{F}\right)$, Table A-2 $\left(2000^{\circ} \mathrm{F}\right)$, and Table A-3 $\left(2400^{\circ} \mathrm{F}\right)$

Optical metallography was performed on two of the titanium alloys (Ti-15-3, Ti-6-4) in order to determine the relationship between test temperature and microstructure (presence of second phase precipitates, grain size). Grain size for the Ti-15-3 alloy was measured by determining the number of grain boundaries that intersect a given length of random line after 1 , 2,5 , and 10 minutes at $2000^{\circ} \mathrm{F}$ The Ti-6-4 alloy specimens were examined after heat-treating and in the area of the grip (where little or no deformation occurred) after tensile tests at $2000^{\circ} \mathrm{F}$ and $2400^{\circ} \mathrm{F}$ were completed.

\section{RESULTS AND DISCUSSION}

\section{METALLOGRAPHY DATA}

The average grain size of the Ti-15-3 alloy after heat-treating measured about $0.05 \mathrm{~mm} /$ grain boundary After soaking for $1 \mathrm{~min}$ at $2000^{\circ} \mathrm{F}$, the average grain size had increased to about $013 \mathrm{~mm} /$ grain boundary $(\mathrm{mm} / \mathrm{gb})$, and the microstructure was completely solution treated (no alpha phase precipitates visible in the beta matrix). After a total of 5 minutes at $2000^{\circ} \mathrm{F}$, grain growth had ceased and the average grain size had stabilized at about $024 \mathrm{~mm} / \mathrm{gb}$. Figure 3 shows a plot of this data The grain size was found to increase rapidly over the first minute, then decrease in growth rate with subsequent heating time The grain size of the as-heat treated Ti-6-4 alloy was extremely small, on the order of $0001 \mathrm{~mm} / \mathrm{gb}$ at room temperature. After testing at $2000^{\circ} \mathrm{F}$, the average grain size had increased to about $0.26 \mathrm{~mm} / \mathrm{gb}$ After testing at $2400^{\circ} \mathrm{F}$, the average grain size had increased to about $032 \mathrm{~mm} / \mathrm{gb}$

\section{TENSILE TEST DATA}

Table 1 lists the titanium alloy tensile test data from tests performed in this study $\left(68^{\circ} \mathrm{F}\right.$, $2000^{\circ} \mathrm{F}$, and $2400^{\circ} \mathrm{F}$ ) and from data compiled from the literature at various strain rates and temperatures (References 4-11). Figure 4 shows the variation in yield stress of the candidate titanium alloys with temperature at a strain rate of $\mathrm{d} \varepsilon / \mathrm{d} t=10^{-3} \mathrm{~s}^{-1}$ It can be seen in Figure $4 \mathrm{a}$ 
that, for all six alloys, the yield stress decreases approximately linearly with increasing temperature up to $1000^{\circ} \mathrm{F}$, at this temperature, the values are about one-half those of room temperature. Above $1400^{\circ} \mathrm{F}$, the yield stresses decrease to less than 10 percent of their room temperature values (data was not available in the temperature range between $1000^{\circ}$ to $1400^{\circ} \mathrm{F}$ ) At temperatures from ambient to $1000^{\circ} \mathrm{F}$, TIMETAL 21S exhibits the highest yield stress ( $210 \mathrm{ksi}$ or $1450 \mathrm{MPa}$ ) of the alloys tested As expected, Ti-6-4 generally exhibits a lower yield stress $(150 \mathrm{ksi}$ or $1035 \mathrm{MPa})$ at all test temperatures than that of the beta alloys. At $2000^{\circ} \mathrm{F}$, the yield stresses are less than $2 \mathrm{ksi}(138 \mathrm{MPa})$; at $2400^{\circ} \mathrm{F}$, they are less than $600 \mathrm{psi}(4 \mathrm{MPa})$ At these very high temperatures, kinetic effects are presumably rapid enough to completely anneal the microstructure through short-range diffusion The ability of the titanium alloys to resist plastic deformation is most likely determined by solid-solution hardening of the structure.

Figure 5 shows the effect (plotted on a log-log scale).strain rate has on yield stress for Ti-6-4 alloy compiled from data tested over a range of 5 orders of magnitude variation in strain rate. Increasing strain rate results in increasing yield (or flow) stress. This behavior is consistent within the temperature range shown (approximately $1400^{\circ}$ to $2400^{\circ} \mathrm{F}$ ). The rate of increase in yield stress is shown to decrease with increasing strain rate Strain-rate sensitivity, $m=\mathrm{d}[\log (\sigma)] / \mathrm{d}[\log (\mathrm{d} \varepsilon / \mathrm{d} t)], 0<m \leq 1$, is a measure of this rate of increase and indicates the ability of a material to resist plastic instability or necking during tensile loading When $m$ is low, an increase in stress at the neck leads to a large increase in strain rate at that location and consequently a low elongation to fracture When $m$ is large, the strain rate increases slowly in response to increased stress in the neck region and the neck forms gradually leading to a high elongation to fracture.

Strain rate sensitivity is known to change with strain, strain rate, temperature, and microstructure Figures $6 \mathrm{a}$ and $6 \mathrm{~b}$ show the effects (plotted on a semi-log scale) of strain rate and temperature, respectively, on strain rate sensitivity of Ti-6-4 alloy (at an approximately constant structure as determined at a constant plastic strain of 02 percent) Strain rate sensitivity is shown to increase with temperature and/or decreasing strain rate. Hence, Ti-6-4 approaches superplastic behavior $(m=1)$ at high temperatures and low strain rates These results are consistent with published data showing the effect of grain size on flow stress and strain rate sensitivity, $m$ as functions of strain rate for Ti-6-4 at $1700^{\circ} \mathrm{F}$ (Reference 12). Strain rate sensitivity, which is shown to decrease with increasing grain size for a given strain rate, increases with decreasing strain rates from $10^{-2} \mathrm{~s}^{-1}$ to about $10^{-4} \mathrm{~s}^{-1}$. For a grain size of $002 \mathrm{~mm}, m$ is reported to increase from 0.3 at a strain rate of $10^{-2} \mathrm{~s}^{-1}$ to about 07 at $\mathrm{d} \varepsilon / \mathrm{d} t=10^{-5} \mathrm{~s}^{-1}$ (Reference 12) Figure 6a shows that for Ti-6-4 data compiled from published test results at $1733 \mathrm{~F}, m$ increases from about 015 at a strain rate of $10^{-1} \mathrm{~s}^{-1}$ to about 08 at de/d $t=10^{-4} \mathrm{~s}^{-1}$ These values would be consistent with Ti-6-4 grain sizes exceeding $002 \mathrm{~mm}$, which is likely to be the case for specimens equilibrated at $1733 \mathrm{~F}$ based on the metallography results of tests at $2000^{\circ} \mathrm{F}$ from this study.

Mechanical properties of $316 \mathrm{~L}(<002 \% \mathrm{C})$ and $316(\sim 0.08 \% \mathrm{C})$ stainless steels are essentially the same; neither alloy contains enough carbon to form the martensite needed to increase strength through a quench and temper process Therefore, tensile yield stress values from the literature were compiled using both $316 \mathrm{~L}$ and 316 stainless steel data (References 1316) (see Table 2). Data for ASTM A387 steel, a 2-1/4Cr-1Mo structural steel also exhibiting relatively good resistance to seawater corrosion, was compiled for comparison with 316 stainlesis steel (Reference 17) 
Figure 7 shows the variation in yield stress of 316 stainless steels ( 316 and $316 \mathrm{~L}$ combined) with temperature The yield stress of annealed 316 stainless steel decreases with increasing temperature Unlike that of titanium alloys, at $1400^{\circ} \mathrm{F}$, the yield stress of 316 stainless steels (annealed or cold worked) is only reduced to about one-half that of its room temperature value. The microstructure of 316 stainless steel is essentially a single phase (austenite with perhaps some retained ferrite) from room temperature up to its melting point and, therefore, solid-solution hardening most likely accounts for the observed resistance to plastic deformation at very high temperatures Prior cold work increases the yield stress of 316 stainless steel substantially up to temperatures of about $1800^{\circ} \mathrm{F}$; above this temperature, the structure is presumably completely annealed and differences in yield stresses are indistinguishable The ability of 316 stainless steel to strain harden at high temperatures (up to about $1800^{\circ} \mathrm{F}$ ) is an important consideration for engineering design It provides an added margin of safety for the CCL by allowing redistribution of stresses within the cylinder material thereby reducing the potential for catastrophic failure during a restrained firing scenario

Figure 8 shows a combined plot of yield stress versus temperature for the titanium alloys, 316 stainless steel, and A387 steel. At temperatures up to $1000^{\circ} \mathrm{F}$, all of the titanium alloys exhibit substantially higher yield stresses than those of the steels. At temperatures somewhere between $1000^{\circ} \mathrm{F}$ and $1500^{\circ} \mathrm{F}$, the microstructural features that contribute to strain hardening (alpha phase precipitates dispersed in the beta alloys) have dissolved into solution and the yield stresses are no greater than (and perhaps not as high as) those of the 316 stainless steel. The yield stresses of annealed and cold worked A387 structural steel are roughly comparable to those of 316 stainless steel up to $1200^{\circ} \mathrm{F}$ (highest temperature where data was available for the $\mathrm{A} 387$ steel). However, the A387 steel appears to lose its increased strength from prior cold work at a lower temperature than that of the stainless steel

\section{SUMMARY}

Room temperature tensile strengths of the titanium alloys evaluated in this study are all very high. TIMETAL $21 \mathrm{~S}$ exhibited the highest yield stress, about $210 \mathrm{ksi}(30 \mathrm{MPa})$, while the other beta alloys were found to yield at stresses of about 140 to $180 \mathrm{ksi}(20$ to $26 \mathrm{MPa}$ ) The Ti-6-4 alloy exhibited a yield stress of about $150 \mathrm{ksi}(22 \mathrm{MPa})$

Yield stresses of all the titanium alloys at temperatures above $2000^{\circ} \mathrm{F}$ were determined to be less than 1 percent of their room temperature values Strain hardening does not occur in any of the alloys tested at these high temperatures Yield stresses were found to increase substantially with increasing strain rate at elevated temperatures due to the high strain rate sensitivity of titanium at high temperatures. This contrasts with room temperature properties, where the titanium alloys are relatively insensitive to strain rate due to their low measured strain rate sensitivity Additionally, strain rate sensitivities were found to increase substantially with increasing temperature and/or decreasing strain rate 


\section{NSWCDD/TR-98/72}

Titanium alloys exhibit yield stresses that are 2 to 4 times higher than that of $316 \mathrm{~L}$ stainless steel at temperatures up to about $1000^{\circ} \mathrm{F}$; above $1500^{\circ} \mathrm{F}$, the yield stress of $316 \mathrm{~L}$ stainless steel is comparable to those of the titanium alloys. The 316 stainless steel is able to strain harden (increase its flow stress with increasing strain) at temperatures up to about $1800^{\circ} \mathrm{F}$. This provides an added margin of safety that may be an important consideration for engineering design of the CCL The yield stress of A387 structural steel was found to be roughly equal to that of 316 stainless steel up to about $1200^{\circ} \mathrm{F}$. Mechanical properties from this study can be used to model an optimum design of the CCL for both the fly-out and restrained firing conditions

\section{ACKNOWLEGMENTS}

This work was also performed under the auspices of the U S. Department of Energy by Lawrence Livermore National Laboratory under contract No W-7405-Eng-48 


\section{REFERENCES}

1. Materials Property Handbook. Titanium Alloys, R Boyer, G. Welsch, and E. W Collings, Editors, ASM International, 1994.

2 Data Sheet for TIMETAL 21S, Titanium Metals Corporation (TIMET), Denver, Colorado

3 Rosenberger, A H "Effect of Vacuum Level on the Embrittlement of TIMETAL 21S," Scripta Materialia, 34, 1996, pp. 1877-1882.

4. O'Connell, T , "TIMETAL 21S," Materials Property Handbook. Titanium Alloys, R. Boyer, G. Welsch, and E W Collings, Editors, ASM International, 1994, pp 921-929

5 Hamilton, C. H, Superplasticity in Titanium Alloys, ASM International, 1985, pp. 13-22

6 Beta Titanium Alloys in the 1980's, R. R. Boyer and H. W. Rosenberg, Editors, TMS/ATME, 1984.

7. Morgan, G C. and Hammond, C., "Superplastic Deformation Properties of B-Ti Alloys," Mater Sci Eng , 86, 1987, pp 159-177

8. Metals Handbook, Properties and Selection. Stainless Steels, Tool Materials, and SpecialPurpose Materials, Vol 3, 9th Edition, American Society for Metals, 1980.

9 McLellan, D L and Eichenberger, T. W ,"Constitutive Equation Development (COED)," Vol 1, Technical Summary, SAMSO-TR-68-320, July 1968, p 80

10 Malcor, J. G., "Mechanical and Microstructural Behavior of Ti-6Al-4V Alloy in the Hot Working Range," Titanium, Science and Technology, G Lutjering, U. Zwicker, and W Bunk, Editors, Deutsche Gesellschaft fur Metallkunde, Germany, 1985, pp. 1495-1502.

11 "Hot Workability of Titanium Alloys," Present Aspects of Titanium Materials Research in Japan, The Iron and Steel Institute of Japan (Nippon Tekko Kyokai), Tokyo, Japan, 1986, pp 30-34 (in Japanese)

12 Paton, N. E, Titanium, Science and Technology, G. Lutjering, U Zwicker, and W Bunk, Editors, Deutsche Gesellschaft fur Metallkunde, Germany, 1985 


\section{REFERENCES (Continued)}

13. Gibbs, T W. and Wyatt, H. W, "Short Time Properties of Type 316 Stainless Steel at Very High Temperatures," Transactions of the ASME Journal of Basic Engineering, Paper No 60-WA-11, 1960.

14 Gibbs, T. W , Kyros, W ; and Theberge, C. L, "Development of a Resistance Heating Facility for the Determination of Tensile Properties of Aircraft and Missile Alloys," Avco Corporation, RaD , TM-63-8, Feb 1963.

15 Albertini, C and Montagnani, M., Nuclear Engineering and Design, 57, 1980, pp. 107123; C. Albertini and M. Montagnani, International Conference on Mechanical Behaviour and Nuclear Applications of Stainless Steels at Elevated Temperatures, Varese, London, Metals Society, 1982.

16 Proceedings of Conference on Stainless Steels '84, Chalmers University of Technology and Jernkontoret (Sweden) and the Metals Society (UK), Chalmers University of Technology, September 3-4, 1984, Goteborg, the Institute of Metals, London, 1985, p 393

17 Kawada, T, Data Sheets on the Elevated Temperature Properties of Normalized and Tempered 2 25-Cr-1Mo Steel for Pressure Vessels (ASTM A387-D), Report 74, National Research Institute for Metals, Tokyo. 


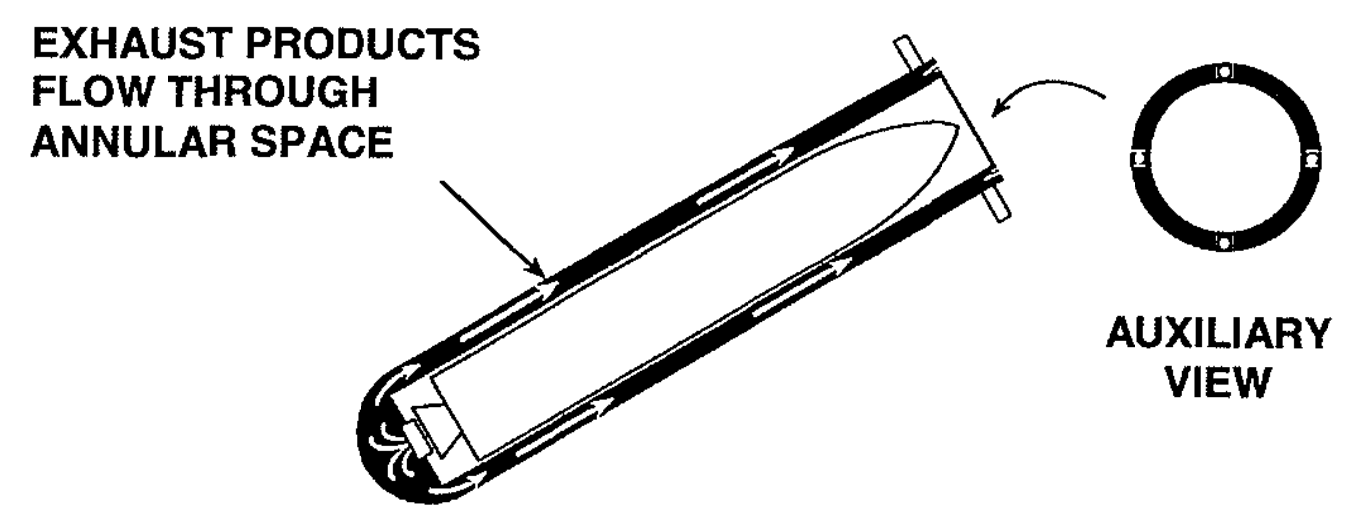

6

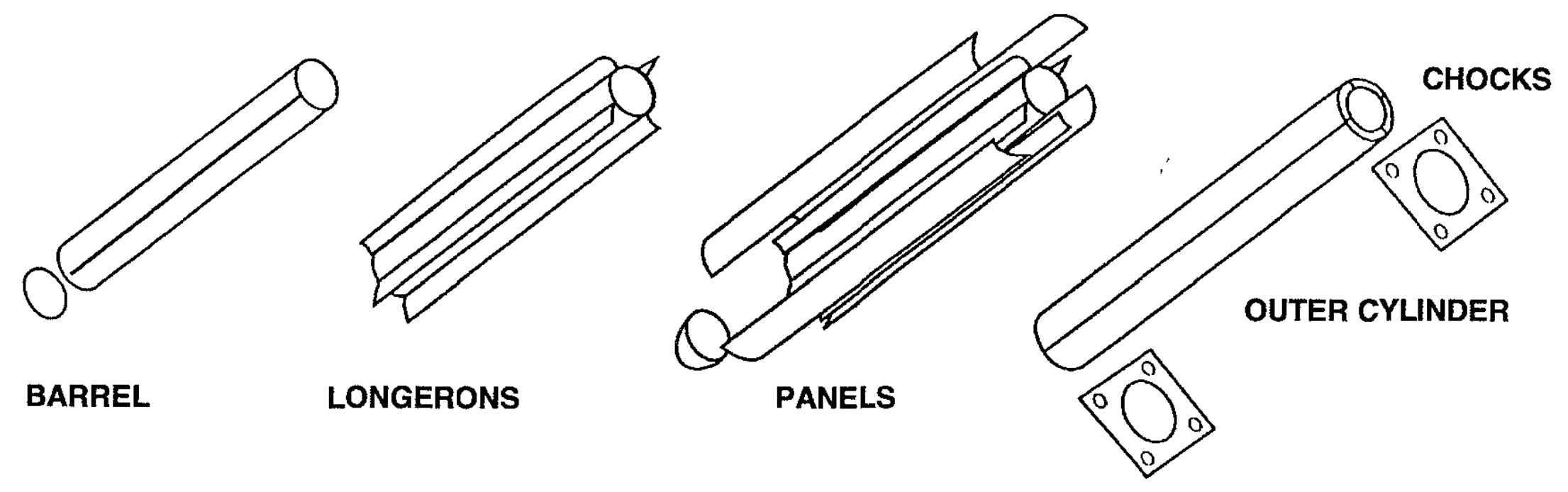




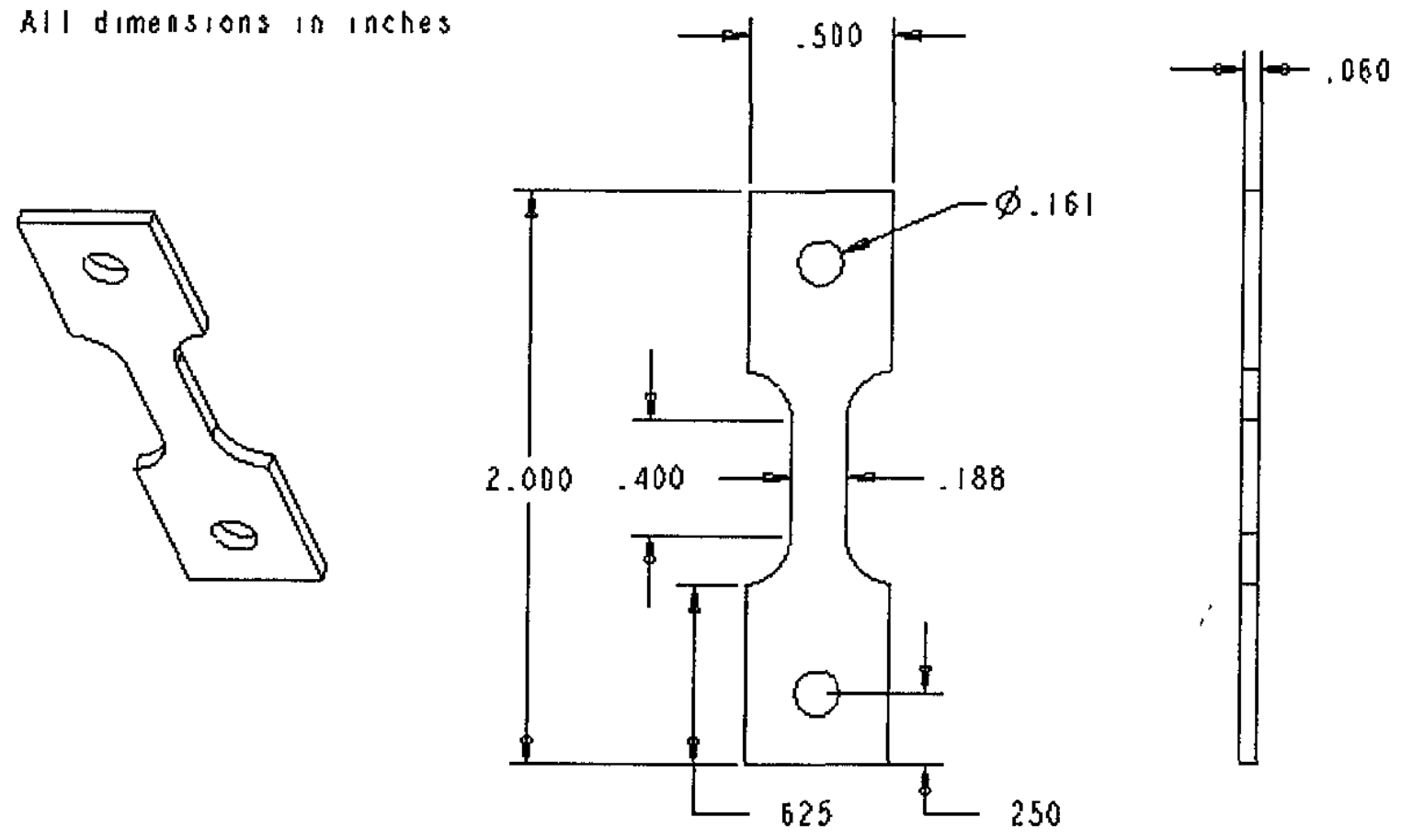




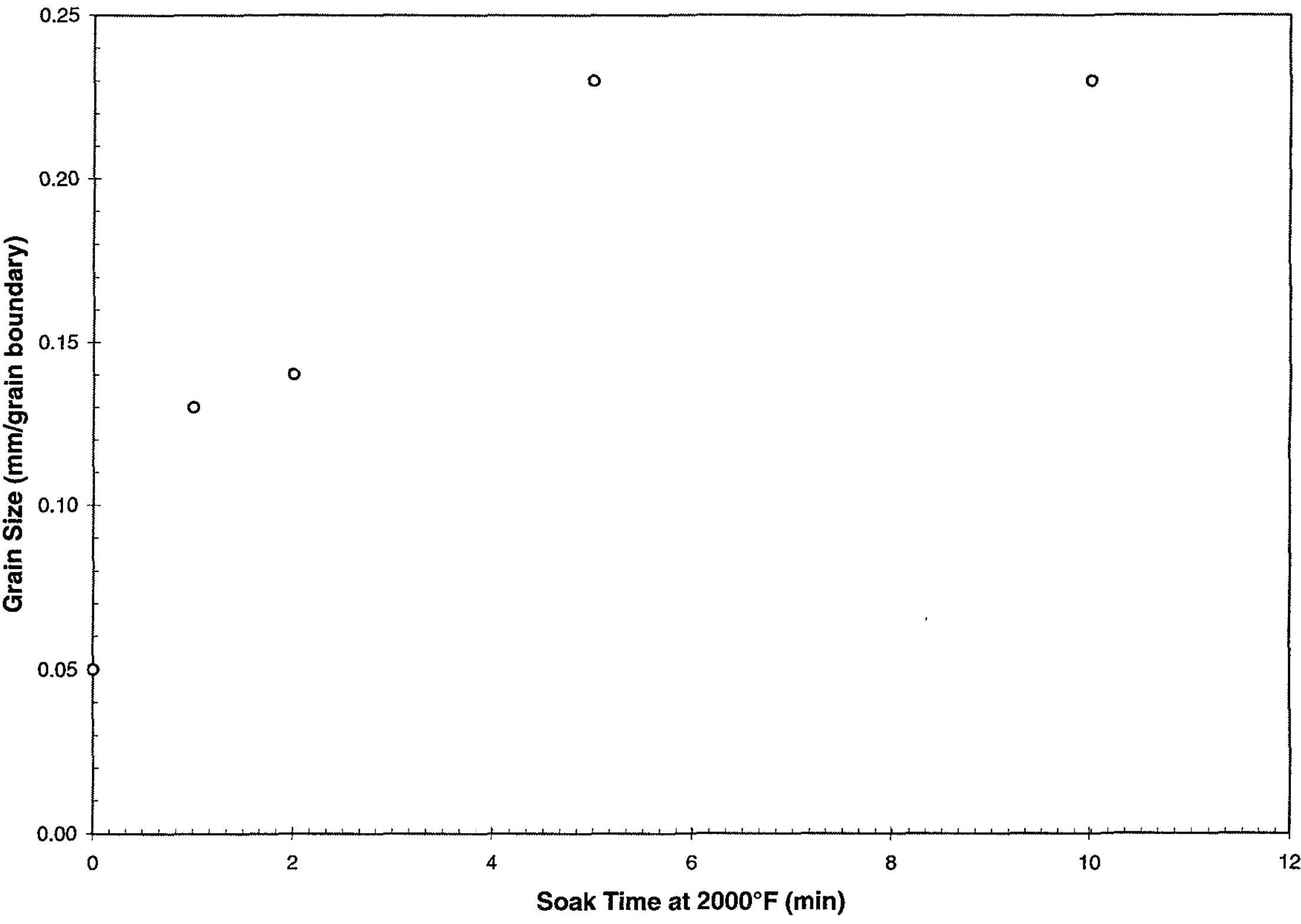

FIGURE 3. INCREASE IN GRAIN SIZE OF Ti-15-3 WITH SOAK TIME AT 2000 $\mathrm{F}$ 


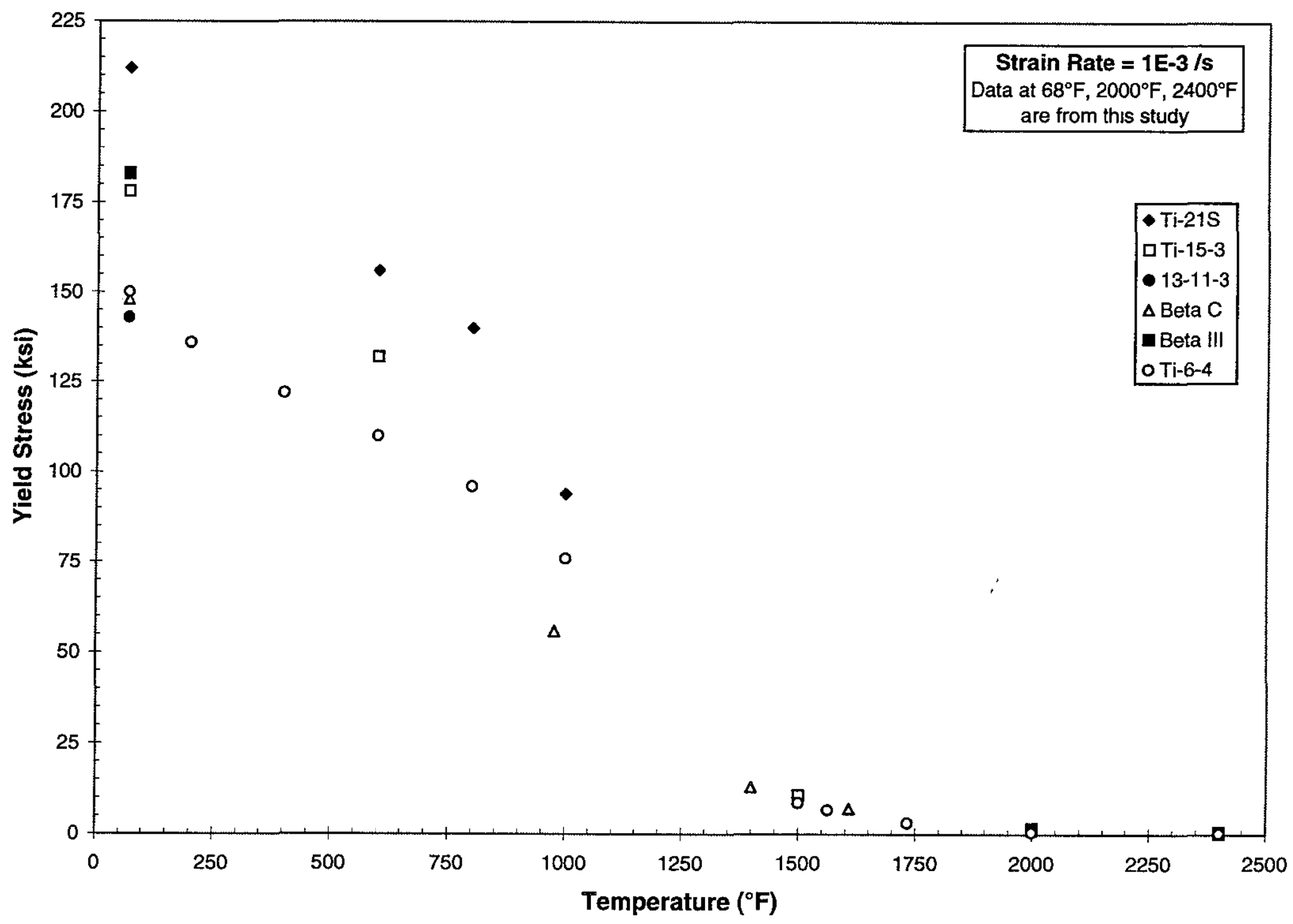

FIGURE 4a. VARIATION IN YIELD STRESS OF TITANIUM ALLOYS WITH TEMPERATURE 


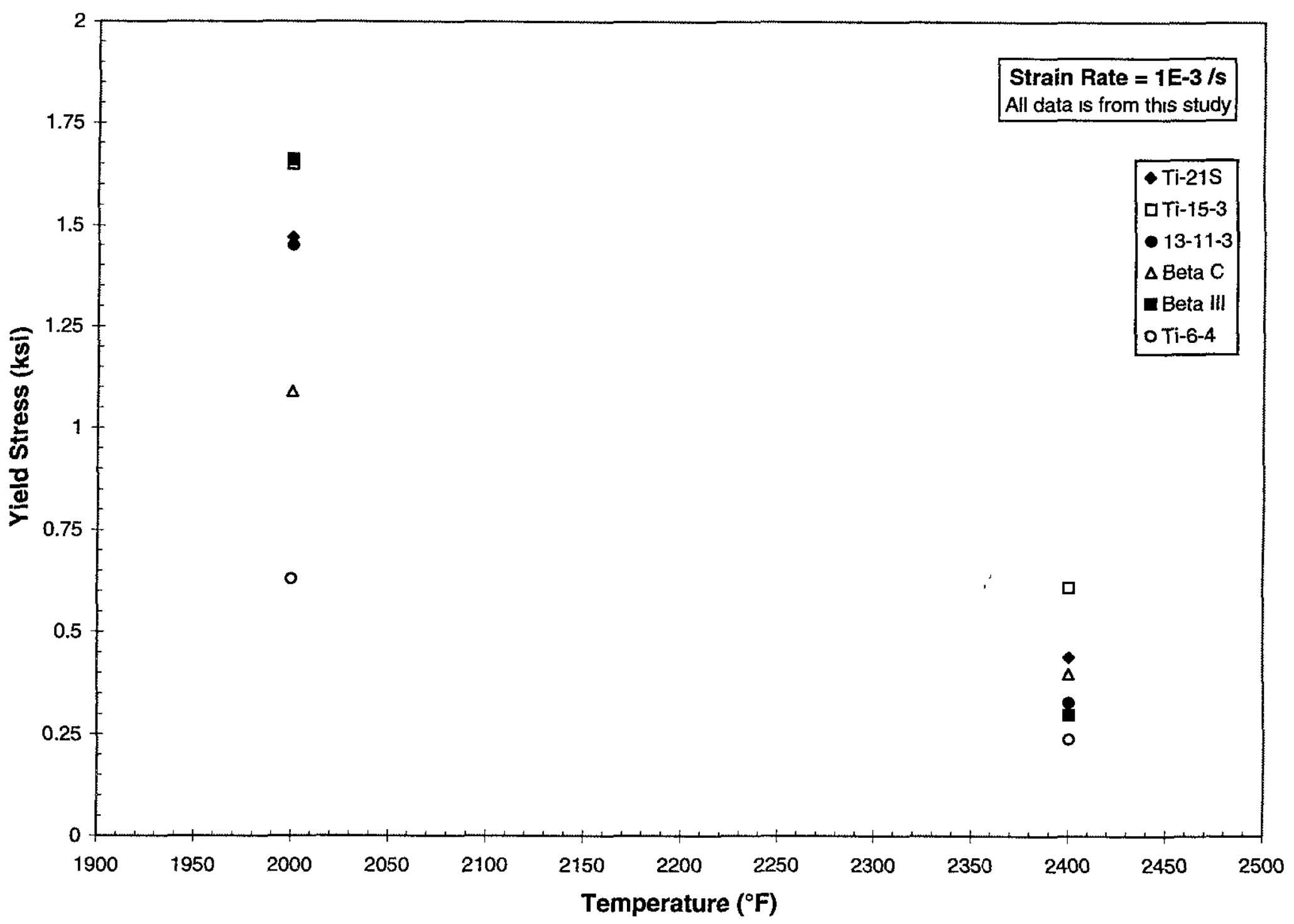

FIGURE 4b. YIELD STRESS OF TITANIUM ALLOYS AT VERY HIGH TEMPERATURES 


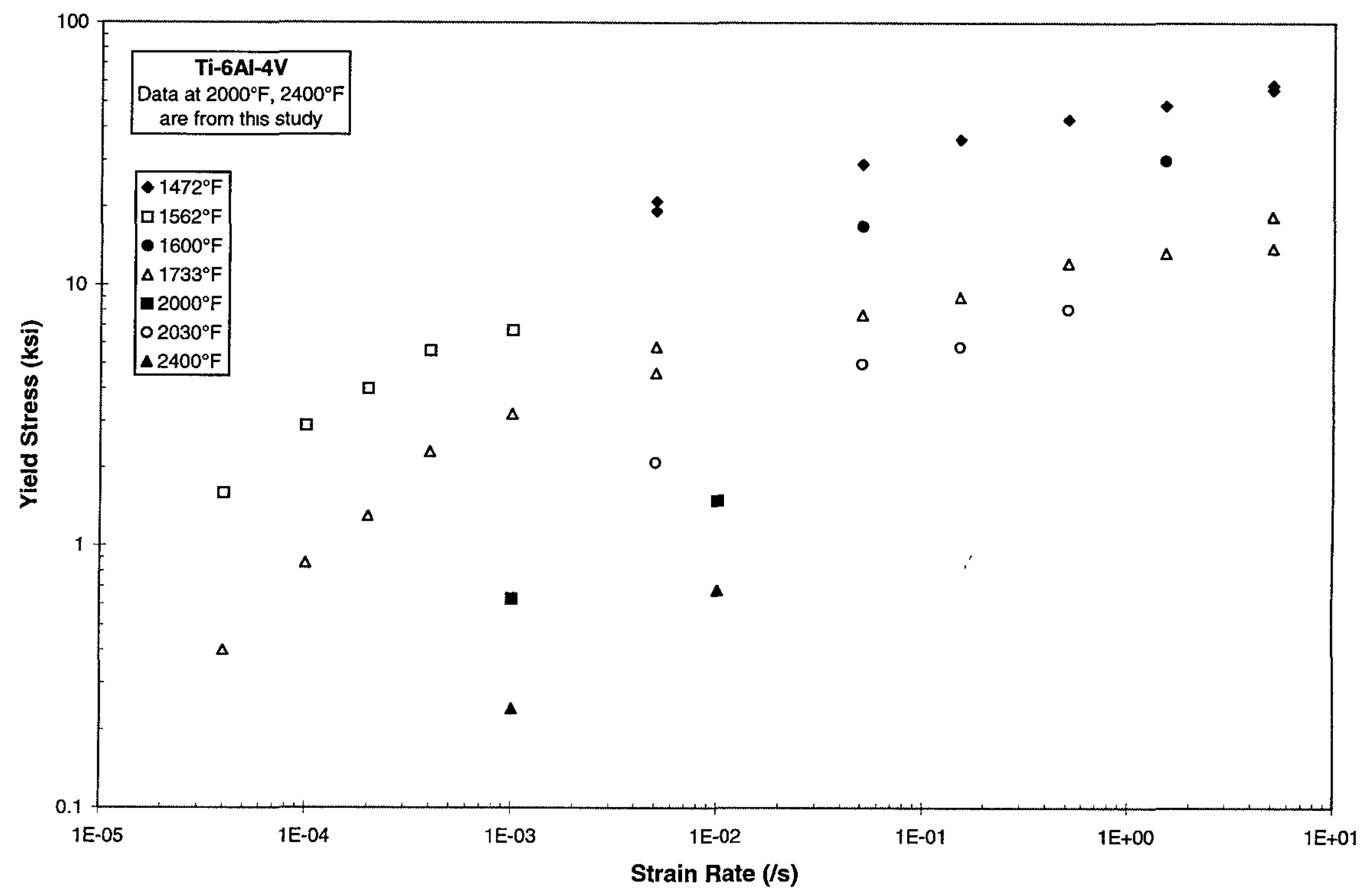

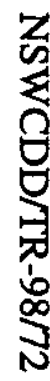

FIGURE 5. VARIATION IN YIELD STRESS OF Ti-6-4 WITH STRAIN RATE 


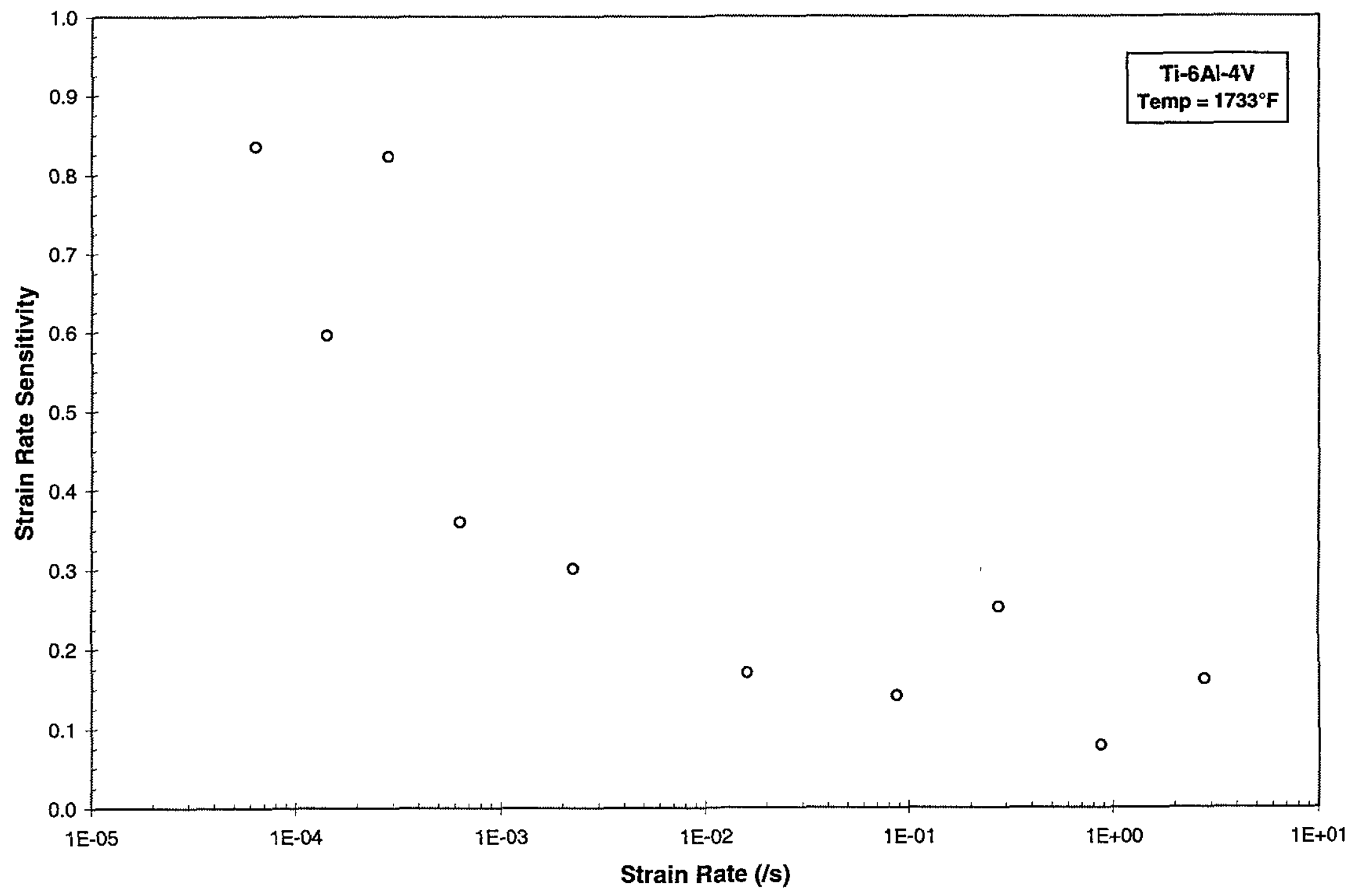

FIGURE 6a. VARIATION IN STRAIN RATE SENSITIVITY OF Ti-6-4 WITH STRAIN RATE 


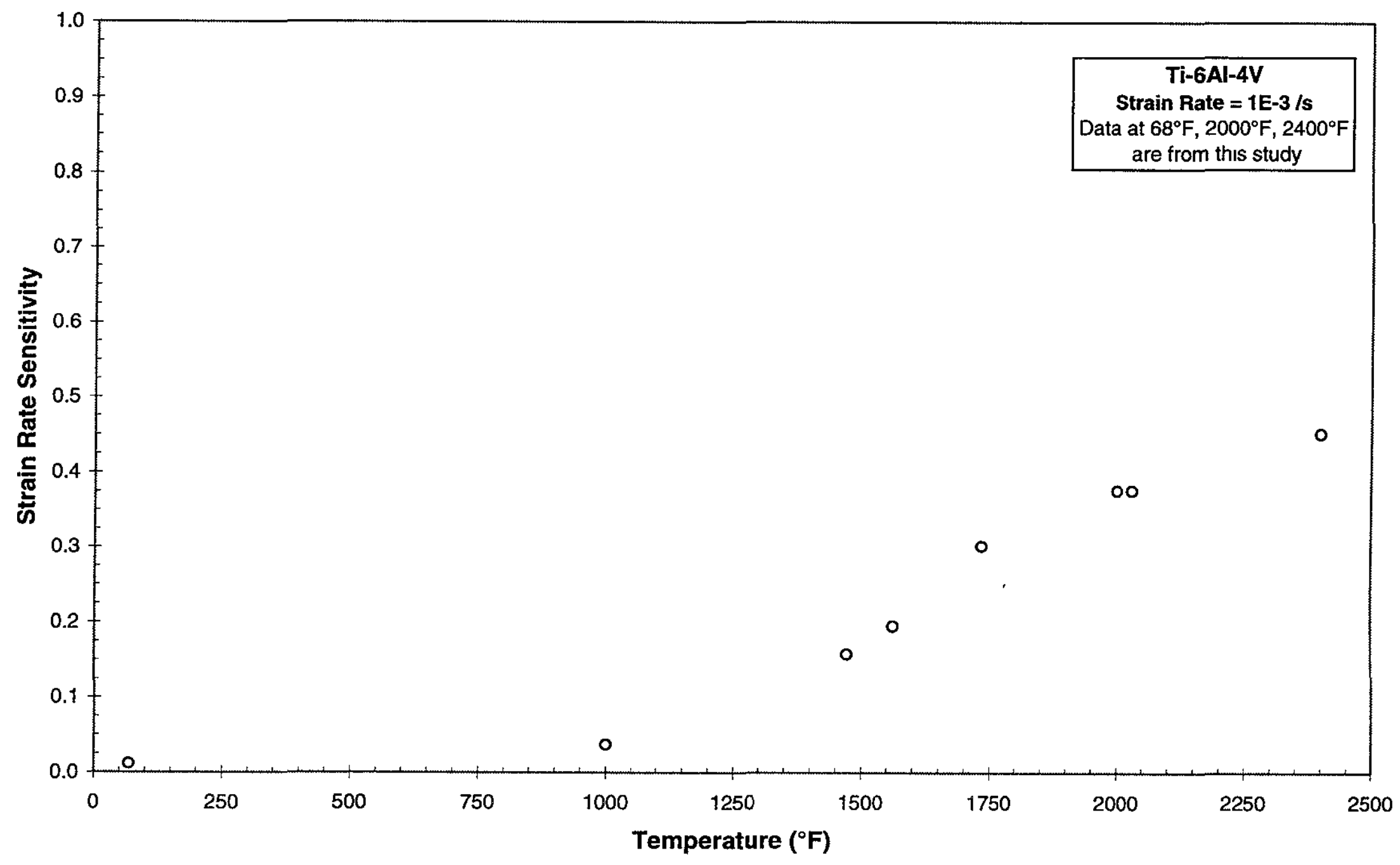

FIGURE 6b. VARIATION IN STRAIN RATE SENSITIVITY OF Ti-6-4 WITH TEMPERATURE 


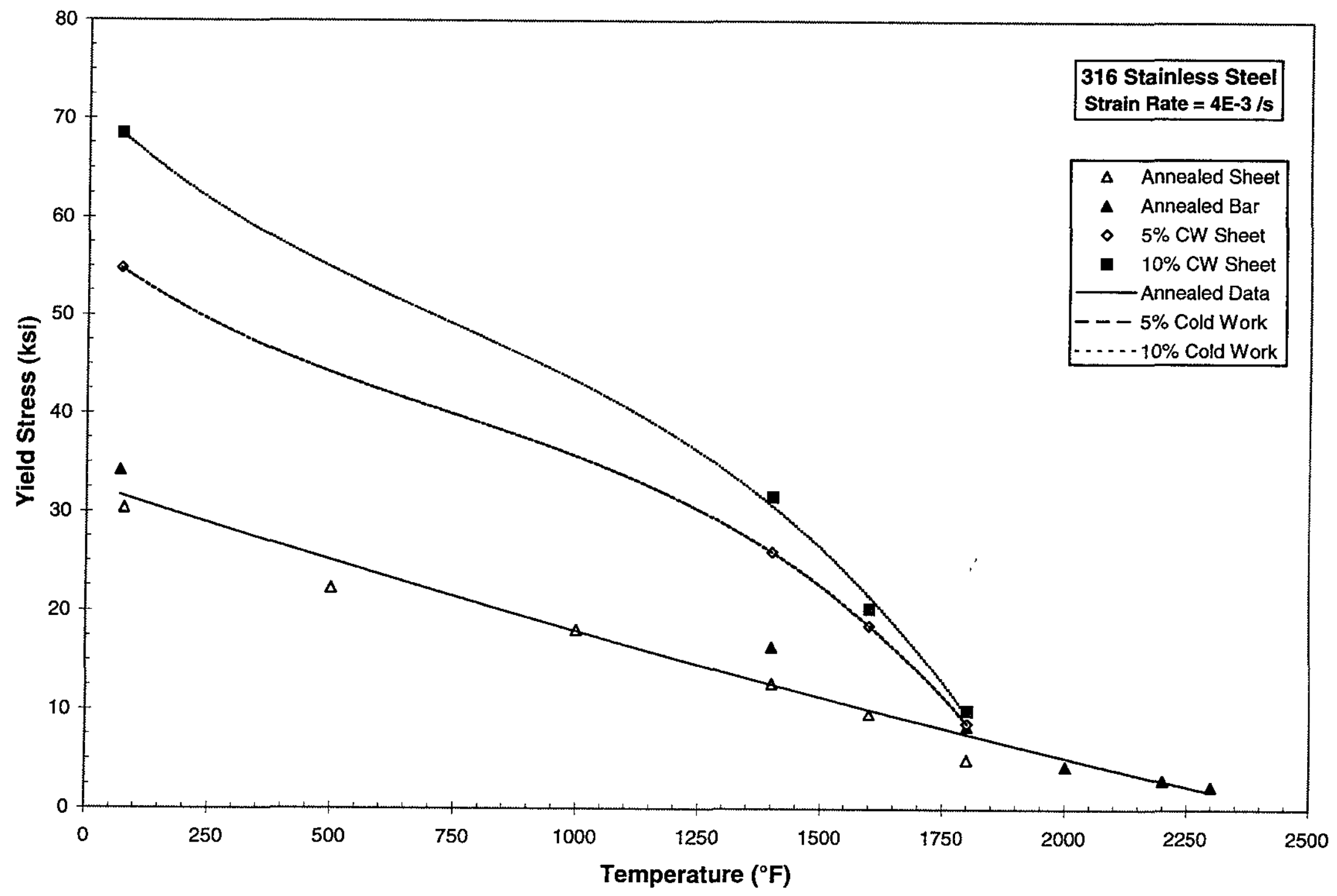

FIGURE 7 VARIATION IN YIELD STRESS OF 316 STAINLESS STEEL WITH TEMPERATURE 


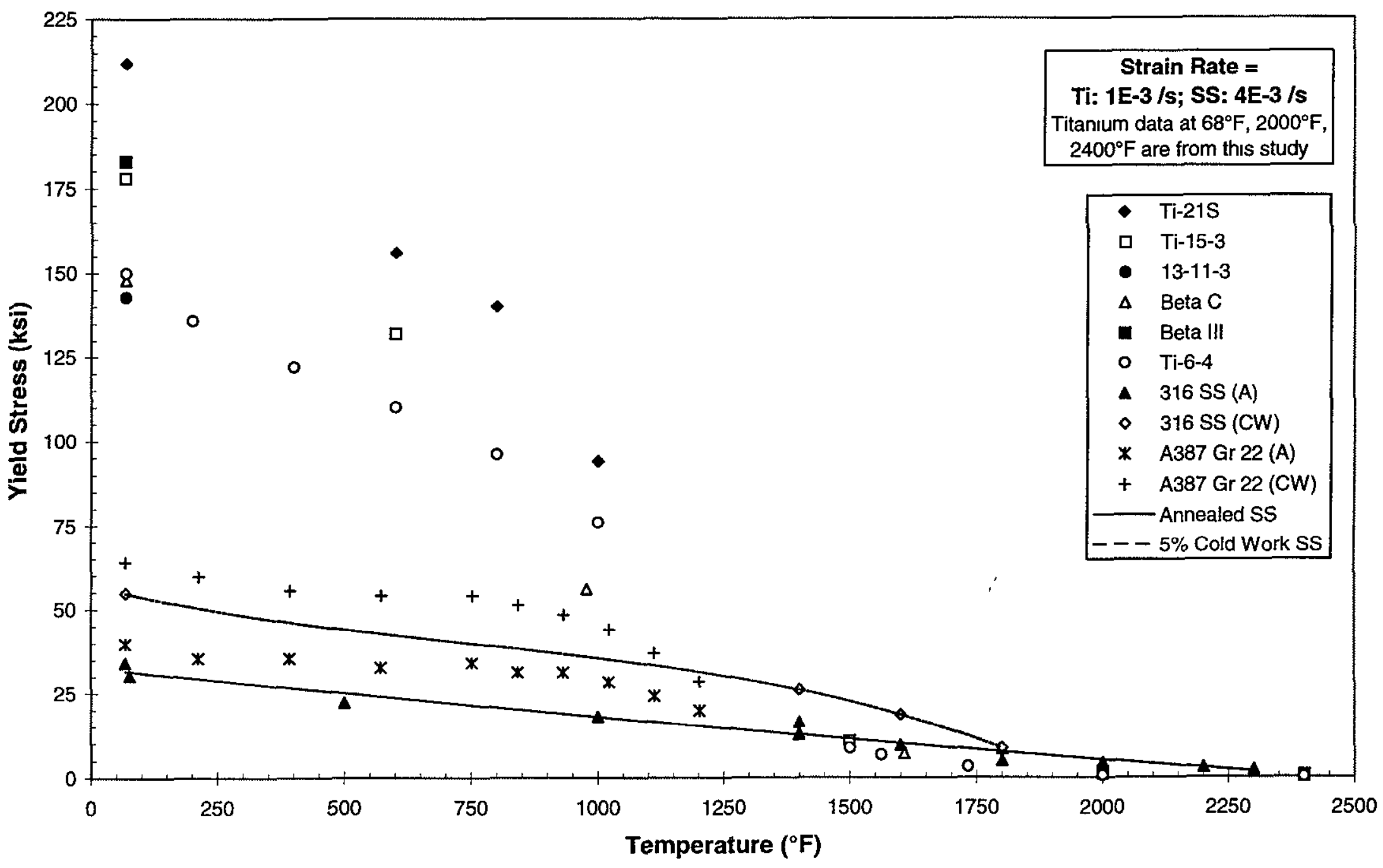

FIGURE 8. VARIATION IN YIELD STRESS OF TITANIUM ALLOYS, 316 STAINLESS STEEL, AND A387 STEEL WITH TEMPERATURE 
TABLE 1. TTTANIUM ALLOY DATA FROM THIS STUDY AND COMPILED FROM THE LITERATURE

\begin{tabular}{|c|c|c|c|c|c|c|c|c|c|c|c|c|c|c|c|c|c|c|c|}
\hline \multicolumn{8}{|c|}{ Yield or Flow Stress of Varıous Titanium Alloys at a Strain Rate of $1 \mathrm{E}-3 / \mathrm{s}$} & & & & & & & & & & Strai & n Rate & \\
\hline & & & & & & & & & & & & & & & & & \multicolumn{3}{|c|}{ Sensitivity of $\mathrm{Ti}-6-4$} \\
\hline $\mathrm{Ti}-21 \mathrm{~S}$ & Ti-21S & & $T i-15-3$ & $T i-15-3$ & & $13-11-3$ & $13-11-3$ & & Beta C & Beta C & & Beta III & Beta III & $T i-6-4$ & $T i-6-4$ & & $T i-6-4$ & $T i-6-4$ & \\
\hline Temp ( $\left.{ }^{\circ} \mathrm{F}\right)$ & YS (ksi) & Ref & $\operatorname{Temp}\left({ }^{a} F\right)$ & Ys (ksi) & Ref & Temp ( $\left.{ }^{\circ} \mathrm{F}\right)$ & YS (ksi) & & Temp ( $\left.{ }^{\circ} \mathrm{F}\right)$ & Ys (ksi) & Ref & Temp $\left({ }^{\circ} \mathrm{F}\right)$ & YS (ksi) & $\operatorname{Temp}\left({ }^{\circ} \mathrm{F}\right)$ & YS (ksi) & Ref & Temp ( $\left.{ }^{\circ} \mathrm{F}\right)$ & $m(1 E-3)$ & Ref \\
\hline 68 & 212 & & 68 & 178 & & 68 & 143 & & 68 & 148 & & 68 & 183 & 68 & 150 & & 68 & 0.011 & \\
\hline 600 & 156 & [4] & 600 & 132 & [5] & 2000 & 1.45 & & 977 & 56 & [6] & 2000 & 1.66 & 200 & 136 & [B] & 1000 & 0.037 & [9] \\
\hline 800 & 140 & [4] & 1500 & 10.7 & [5] & 2400 & 0.33 & & 1400 & 13 & {$[7]$} & 2400 & 0.3 & 400 & 122 & [8] & 1472 & 0.16 & [10] \\
\hline 1000 & 94 & [4] & 2000 & 1.65 & & & & & 1607 & 71 & [7] & & & 600 & 110 & [8] & 1562 & 0.20 & [5] \\
\hline 2000 & 1.47 & & 2400 & 0.61 & & & & & 2000 & 1.09 & & & & 800 & 96 & [B] & 1733 & 0.30 & [5] \\
\hline \multirow[t]{6}{*}{2400} & 0.44 & & & & & & & & 2400 & 0.4 & & & & 1000 & 76 & [8] & 2000 & 0.38 & \\
\hline & & & & & & & & & & & & & & 1500 & 8.7 & [5] & 2030 & 0.38 & [10] \\
\hline & & & & & & & & & & & & & & 1562 & 6.7 & [5] & 2400 & 0.45 & \\
\hline & & & & & & & & & & & & & & 1733 & 3.2 & [5] & & & \\
\hline & & & & & & & & & & & & & & 2000 & 0.63 & & & & \\
\hline & & & & & & & & & & & & & & 2400 & 0.24 & & & & \\
\hline \multicolumn{9}{|c|}{ Yield or Flow Stress of Ti-6AI-4V at Various Strain Rates and Temperatures } & & & & & & & & & \multirow{2}{*}{\multicolumn{2}{|c|}{\begin{tabular}{|c|} 
Strain Rate \\
Sensitivity of $\mathrm{TI}-6-4$ \\
\end{tabular}}} & \\
\hline & & & & & & & & & & & & & & & & & & & \\
\hline $1472^{\circ} \mathrm{F}$ & $1472^{\circ} \mathbf{F}$ & & $1733^{\circ} \mathrm{F}$ & $1733^{\circ} \mathrm{F}$ & & $2030^{\circ} \mathrm{F}$ & $2030^{\circ} \mathrm{F}$ & & $2000^{\circ} \mathrm{F}$ & $2000^{\circ} \mathrm{F}$ & & $2400^{\circ} \mathrm{F}$ & $2400^{\circ} \mathrm{F}$ & $1562^{\circ} \mathrm{F}$ & $1562^{\circ} \mathrm{F}$ & & Avg Strain & $\mathbf{m}$ & \\
\hline \multirow[t]{6}{*}{ Rate $(/ s)$} & YS (ksi) & Ref & Rate (/s) & YS (ksi) & Bef & Rate (s) & YS (ksi) & Ref & Rate (/s) & YS (ksi) & & Rate (/s) & YS (ksi) & Rate (s) & YS (ksi) & Ret & Rate $(1 / 8)$ & $\left(1733^{\circ} \mathrm{F}\right)$ & Ref \\
\hline & & & $4.00 \mathrm{E}-05$ & 0.4 & [5] & & & & & & & & & $4.00 \mathrm{E}-05$ & 1.6 & [5] & & & \\
\hline & & & $1.00 \mathrm{E}-04$ & 0.86 & [5] & & & & & & & & & $1.00 \mathrm{E}-04$ & 2.9 & [5] & 6.32E-05 & 0.84 & [5] \\
\hline & & & $2.00 \mathrm{E}-04$ & 1.3 & [5] & & & & & & & & & $2.00 \mathrm{E}-04$ & 4 & [5] & 1.41E-04 & 0.60 & [5] \\
\hline & & & $4.00 \mathrm{E}-04$ & 2.3 & [5] & & & & & & & & & $4.00 \mathrm{E}-04$ & 5.6 & [5] & $2.83 E-04$ & 0.82 & [5] \\
\hline & & & $1.00 \mathrm{E}-03$ & 3.2 & [5] & & & & & & & & & $1.00 \mathrm{E}-03$ & 6.7 & [5] & $6.32 \mathrm{E}-04$ & 0.36 & [5] \\
\hline $5.00 \mathrm{E}-03$ & 19.3 & [11] & $5.00 \mathrm{E}-03$ & 5.8 & [11] & & & & & & & & & & & & 2.24E-03 & 0.30 & [5] \\
\hline $5.00 \mathrm{E}-03$ & 21 & [10] & $5.00 \mathrm{E}-03$ & 4.6 & [10] & $5.00 \mathrm{E}-03$ & 2.1 & [10] & $1.00 \mathrm{E}-03$ & 0.63 & & $1.00 \mathrm{E}-03$ & 0.24 & & & & & & \\
\hline 5.00E-02 & 29 & [10] & $5.00 \mathrm{E}-02$ & 7.7 & [10] & $5.00 \mathrm{E}-02$ & 5 & [10] & $1.00 \mathrm{E}-02$ & 1.5 & & $1.00 \mathrm{E}-02$ & 0.68 & $1600^{\circ} \mathrm{F}$ & $1600^{\circ} \mathrm{F}$ & & $1.58 \mathrm{E}-02$ & 0.17 & [10] \\
\hline 0.15 & 36 & [10] & 0.15 & 9 & [10] & 0.15 & 5.8 & {$[10]$} & & & & & & Rate (/s) & YS (ksi) & Bef & $8.66 \mathrm{E}-02$ & 0.14 & [10] \\
\hline 0.5 & 43 & [10] & 0.5 & 12.2 & [10] & 0.5 & 8.1[ & [10] & & & & & & $5.00 \mathrm{E}-02$ & 16.9 & [10] & 2.74E-01 & 0.25 & {$[10]$} \\
\hline 1.5 & 48.5 & [10] & 1.5 & 13.3 & [10] & 1.5 & 9.3[ & [10] & & & & & & 1.5 & 30 & [10] & 8.66E-01 & 0.08 & {$[10]$} \\
\hline 5 & 58 & [10] & 5 & 18.4 & [10] & 5 & 11.6 & [10] & & & & & & & & & $2.74 E+\infty 0$ & 0.16 & [10] \\
\hline 5 & 55.7 & [11] & 5 & 13.9 & [11] & & & & & & & & & & & & & & \\
\hline
\end{tabular}


TABLE 2. TYPE 316 STAINLESS STEEL AND A387 STEEL DATA COMPILED FROM THE LITERATURE

\begin{tabular}{|c|c|c|c|c|c|c|c|c|c|c|c|c|c|c|c|}
\hline \multicolumn{5}{|c|}{ Yield Stress of Annealed 316 SS at 4E-3/s } & & \multicolumn{3}{|c|}{316 SS Yield Stress } & \multicolumn{3}{|c|}{316 SS Yield Stress } & \multirow{2}{*}{\multicolumn{3}{|c|}{\begin{tabular}{|c|} 
A387 Grade 22 \\
(Normalized and Tempered) \\
\end{tabular}}} & \\
\hline \multirow{3}{*}{$\begin{array}{l}3 / 4 \text { in. Bar } \\
\left.\text { Temp ( }{ }^{\circ} \mathrm{F}\right)\end{array}$} & \multirow{3}{*}{$\begin{array}{c}/ 4 \text { In. Bar } \\
\text { YS (ksi) }\end{array}$} & \multirow{3}{*}{ Ref } & \multirow{3}{*}{$\begin{array}{l}\text { 1/8 Sheet } \\
\left.\text { Temp ( }{ }^{\circ} \mathrm{F}\right)\end{array}$} & \multirow{3}{*}{$\begin{array}{l}\text { 1/8 Sheet } \\
\text { YS (ksi) }\end{array}$} & \multirow[b]{3}{*}{ Ref } & \multicolumn{2}{|c|}{ (5\% Cold Work) } & & \multicolumn{2}{|c|}{ (10\% Cold Work) } & \multirow[b]{3}{*}{ Ref } & & & & \\
\hline & & & & & & \multirow{2}{*}{$\begin{array}{c}\text { Temp } \\
\left.{ }^{\circ} \mathbf{F}\right) \\
\end{array}$} & \multirow{2}{*}{\begin{tabular}{|c|} 
YS \\
(ksi) \\
\end{tabular}} & \multirow[b]{2}{*}{ Ref } & \multirow{2}{*}{$\begin{array}{c}\text { Temp } \\
\left.{ }^{\circ} \mathrm{F}\right) \\
\end{array}$} & \multirow{2}{*}{$\begin{array}{c}\text { YS } \\
\text { (ksi) } \\
\end{array}$} & & \multirow{2}{*}{$\frac{\text { Temp }}{\left({ }^{\circ} \mathrm{F}\right)}$} & \multicolumn{2}{|c|}{ YS (ksi) } & \\
\hline & & & & & & & & & & & & & Annealed & CW & Ref \\
\hline 68 & 34.2 & [13] & 77 & 30.4 & [14] & 68 & 54.8 & [13] & 68 & 68.5 & [13] & 68 & 39.8 & 64.0 & {$[17]$} \\
\hline 1400 & 16.4 & [13] & 500 & 22.3 & [14] & 1400 & 26 & [13] & 1400 & 31.6 & [13] & 212 & 35.6 & 59.7 & {$[17]$} \\
\hline 1800 & 8.35 & [13] & 1000 & 18.1 & [14] & 1600 & 18.6 & [13] & 1600 & 20.3 & [13] & 392 & 35.6 & 55.5 & [17] \\
\hline 2000 & 4.35 & [13] & 1400 & 12.7 & [14] & 1800 & 8.7 & [13] & 1800 & 10 & [13] & 572 & 32.7 & 54.1 & {$[17]$} \\
\hline 2200 & 3 & [13] & 1600 & 9.6 & [14] & & & & & & & 752 & 34.1 & 54.1 & {$[17]$} \\
\hline \multirow[t]{2}{*}{2300} & 2.36 & [13] & 1800 & 5 & [14] & & & & & & & 842 & 31.3 & 51.2 & {$[17]$} \\
\hline & & & & & & & & & & & & 932 & 31.3 & 48.4 & {$[17]$} \\
\hline \multicolumn{5}{|c|}{ Yield Stress of As-Received 316L SS } & & & \multicolumn{4}{|c|}{ Strain Rate Sensitivity of 316L SS } & & 1022 & 28.4 & 44.1 & {$[17]$} \\
\hline & & & & & & & & & & & & 1112 & 24.2 & 37.0 & {$[17]$} \\
\hline $68^{\circ} \mathrm{F}$ & $68^{\circ} \mathrm{F}$ & & $1022^{\circ} \mathrm{F}$ & $1022^{\circ} \mathrm{F}$ & & Strain Rate & $\mathbf{m}$ & & Strain Rate & $\mathbf{m}$ & & 1202 & 19.9 & 28.4 & {$[17]$} \\
\hline Rate $(/ \mathrm{s})$ & YS (ksi) & Ref & Rate (/s) & YS (ksi) & Ref & (/s) & (68 F) & Ref & $(/ \mathrm{s})$ & $\left(1022^{\circ} \mathrm{F}\right)$ & Ref & & & & \\
\hline 4.00E-03 & 46 & [15] & $3.50 E-04$ & 21 & [16] & & & & & & & & & & \\
\hline \multirow[t]{2}{*}{15} & 65 & [15] & 3.50 & 26 & [16] & $3.50 E-02$ & 0.042 & [15] & $3.50 \mathrm{E}-02$ & 0.023 & [16] & & & & \\
\hline & & & $7.80 E+02$ & 33 & [16] & & & & $5.22 E+01$ & 0.044 & [16] & & & & \\
\hline
\end{tabular}


NSWCDD/TR-98/72

APPENDIX A

\section{TITANIUM ALLOY TEST DATA}


TABLE A-1. TITANIUM ALLOY DATA FROM TESTS AT ROOM TEMPERATURE $\left(68^{\circ} \mathrm{F}\right)$

\begin{tabular}{|c|c|c|c|c|c|c|c|c|c|c|c|c|c|c|c|}
\hline \multicolumn{16}{|c|}{ Titanıum Alloy Test Data } \\
\hline \multicolumn{16}{|c|}{ Temp: $20^{\circ} \mathrm{C}$} \\
\hline Strain Rate $(/ \mathrm{s})$ & & & & $100 E-6$ & $1 E-3$ & $100 E-6$ & $10 E-3$ & $100 E-6$ & $10 \mathrm{E}-3$ & $100 \mathrm{E}-6$ & $10 \mathrm{E}-3$ & $100 E-6$ & $10 E-3$ & $\begin{array}{l}10^{-4} / \mathrm{s}-> \\
0.01 / \mathrm{s}\end{array}$ & $\begin{array}{c}10^{-4} / \mathrm{s}-\mathrm{s} \\
0.01 / \mathrm{s}\end{array}$ \\
\hline ALLOY & Heat Treat* & Test & $\begin{array}{l}\text { Strain Rate } \\
\text { Test Type }\end{array}$ & $\begin{array}{c}0.2 \% \\
Y . S .(k s i)\end{array}$ & $\begin{array}{l}\text { Y.S.**** } \\
\text { (ksi) }\end{array}$ & $\begin{array}{c}\text { ENGR } \\
\text { UTS (ksi) }\end{array}$ & $\begin{array}{c}\text { ENGR } \\
\text { UTS (ksi) }\end{array}$ & $\begin{array}{c}\text { True } \\
\text { Fracture } \\
\text { (ksi) }\end{array}$ & $\begin{array}{c}\text { True } \\
\text { Fracture } \\
\text { (ksi) }\end{array}$ & $\% R A$ & $\% R A^{\star \star}$ & \%Elong & \%Elong & $\mathrm{N}$ & $\mathrm{m}$ \\
\hline TIMETAL 21S & $593 \mathrm{C}, 8 \mathrm{~h}$ & $\# 1$ & Constant & 145 & & 154 & & 191 & & 28.1 & & 20.8 & & & \\
\hline TIMETAL 21S & $480 \mathrm{C}, 20 \mathrm{~h}$ & $\# 2$ & Constant & 200 & & 206 & & 224 & & 9.2 & & 8.3 & & & \\
\hline TIMETAL 21S & $480 \mathrm{C}, 20 \mathrm{~h}$ & $\# 3$ & Change & 208 & 212 & & 220 & & 242 & & 9.7 & & 6.9 & 122 & 0.0082 \\
\hline Ti-6-4 & $540 \mathrm{C}, 4 \mathrm{~h}$ & $\# 1^{* * *}$ & Constant & $\star \star \star \star$ & & 153 & & 178 & & 14.6 & & 13.5 & & & \\
\hline Ti-6-4 & $540 \mathrm{C}, 4 \mathrm{~h}$ & $\# 2$ & Change & 146 & 150 & & 161 & & 191 & & 25.9 & & 18.4 & 88 & 0.0114 \\
\hline Ti-15-3 & $510 \mathrm{C}, 14 \mathrm{~h}$ & $\# 1$ & Constant & 171 & & 184 & & 211 & & 19.9 & & 13.8 & & & \\
\hline Ti-15-3 & $510 \mathrm{C}, 14 \mathrm{~h}$ & $\# 2$ & Change & 175 & 178 & & 195 & & 214 & & 20.0 & & 12.3 & 129 & 0.0078 \\
\hline Ti-13-11-3 & $480 \mathrm{C}, 72 \mathrm{~h}$ & $\# 1$ & Constant & 137 & & 141 & & 147 & & 4.4 & & 4.0 & & & \\
\hline Ti-13-11-3 & $480 \mathrm{C}, 72 \mathrm{~h}$ & $\# 2$ & Change & 140 & 143 & & 152 & & 157 & & 3.5 & & 3.5 & 108 & 0.0093 \\
\hline Beta C & $480 \mathrm{C}, 16 \mathrm{~h}$ & $\# 1$ & Constant & 150 & & 160 & & 185 & & 14.8 & & 11.6 & & & \\
\hline Beta C & $480 \mathrm{C}, 16 \mathrm{~h}$ & $\# 2$ & Change & 148 & 151 & & 165 & & 188 & & 15.0 & & 12.0 & 122 & 0.0082 \\
\hline Beta III & $480 \mathrm{C}, 8 \mathrm{~h}$ & $\# 3$ & Change & 176 & 183 & & 204 & & 220 & & 10.5 & & 7.5 & 62 & 0.0161 \\
\hline & & & & & & & & & & & & & & & \\
\hline \multicolumn{16}{|c|}{ "All specimens solution treated at $815^{\circ} \mathrm{C}$ for $15 \mathrm{~min}$ prior to aging at temperatures and times indicated. } \\
\hline \multirow{2}{*}{\multicolumn{16}{|c|}{ **Test \#1 of the Ti-6-4 broke near the shoulder. This may have been a premature fracture, resulting in lower d }} \\
\hline & & & & & & & & & & & & & & & \\
\hline \multicolumn{7}{|c|}{${ }^{* * *}$ Yield stress is calculated using the constant structure stress exponent, $\mathrm{N}$. } & & & & & & & & & \\
\hline
\end{tabular}


TABLE A-2. TITANIUM ALLOY DATA FROM TESTS AT $2000^{\circ} \mathrm{F}$

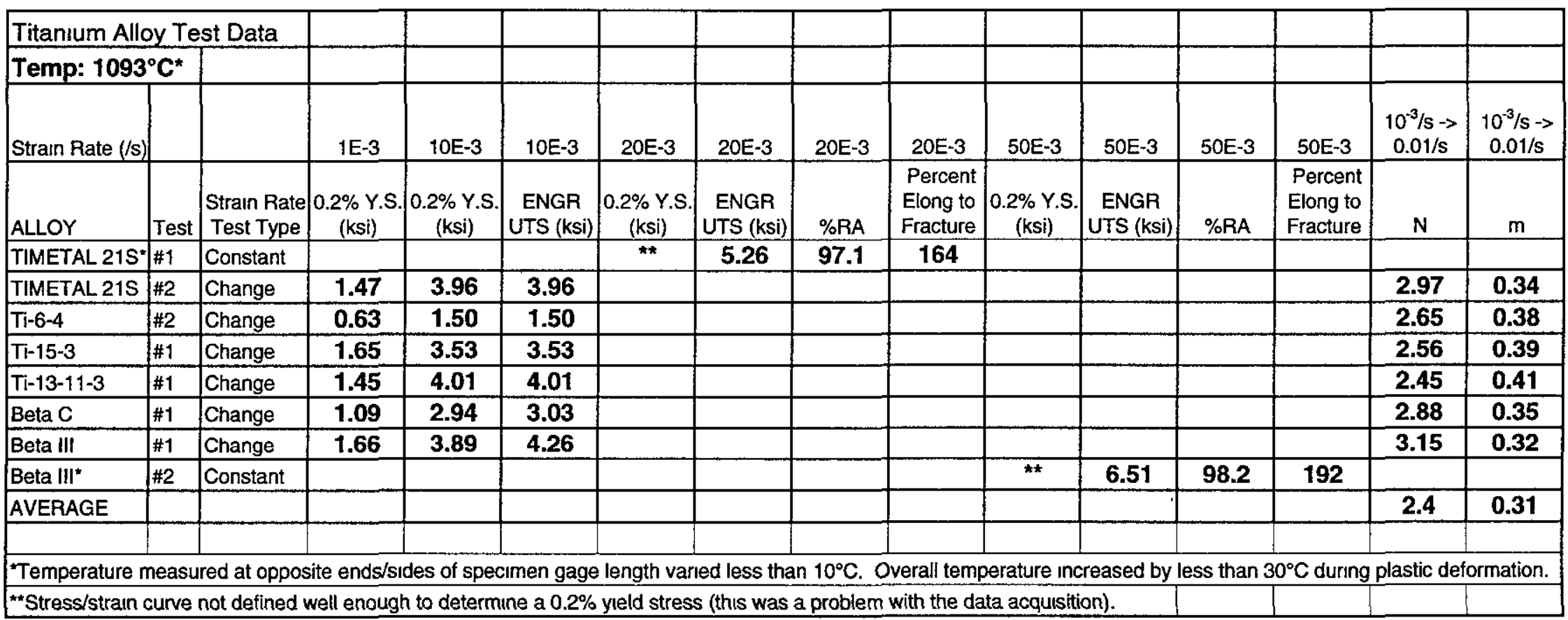


TABLE A-3. TITANIUM ALLOY DATA FROM TESTS AT $2400^{\circ} \mathrm{F}$

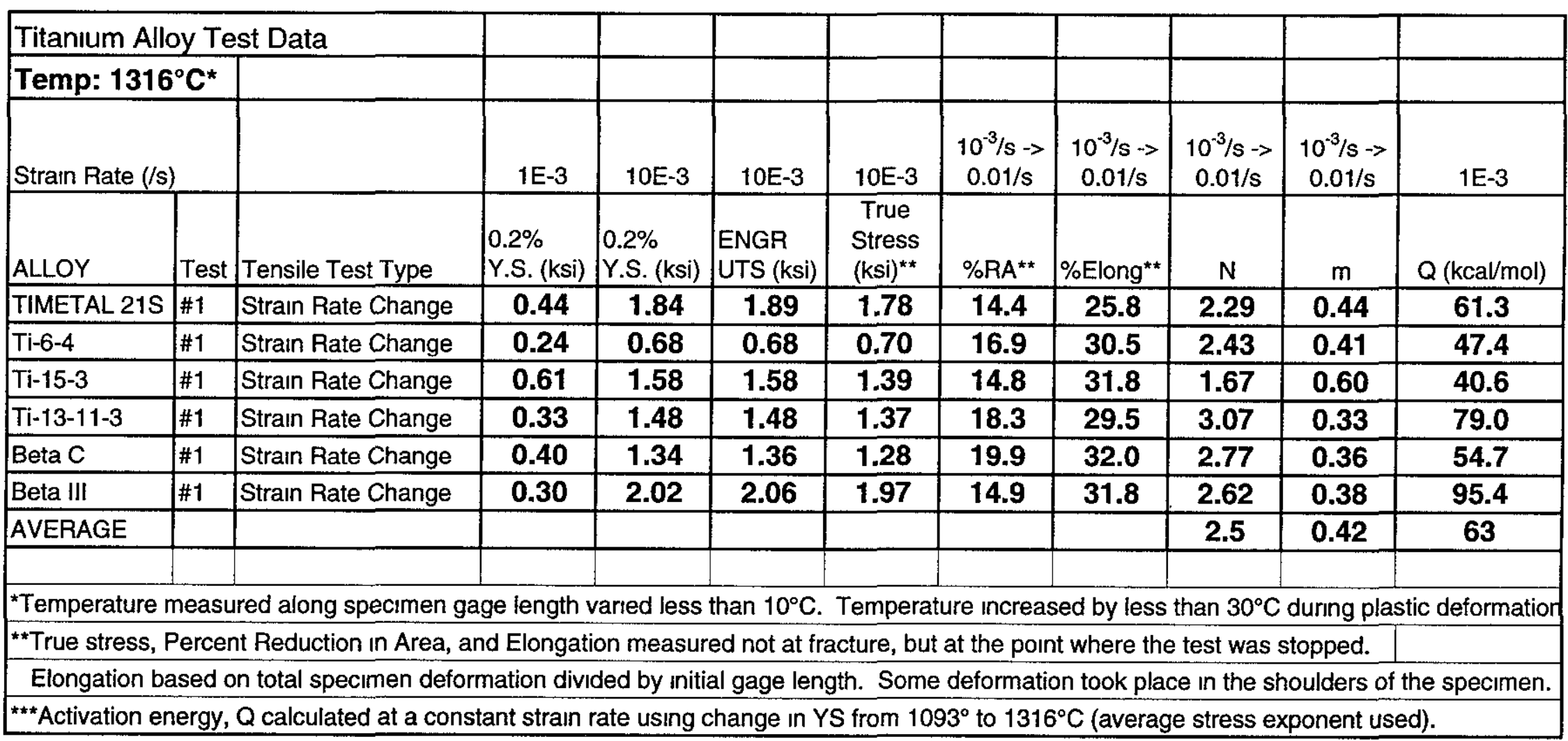




\section{DISTRIBUTION}

DOD ACTIVITIES (CONUS)

DEFENSE TECH INFORMATION CTR 8725 JOHN J KINGMAN RD SUITE 0944

FORT BELVOIR VA $22060-6218$

ATTN CODE A76 (TECHNICAL LIBRARY)

COMMANDING OFFICER

CSSDD NSWC

6703 W HIGHWAY 98

PANAMA CITY FL 32407-7001

ATTN CODE N43 (RADM KNAPP)

COMMANDER

NAVAL SURFACE FORCE

U S ATLANTIC FLEET

1430 MITSCHER AVE

NORFOLK VA 23551-2494

ATTN CODE 35

(JAMES CHEW)

(DAVE SIEGEL)

(ELI ZIMET)

OFFICE OF NAVAL RESEARCH

$800 \mathrm{~N}$ QUINCY ST

ARLINGTON VA 22217-5000

ATTN CODE N86

CHIEF OF NAVAL OPERATIONS

SURFACE WARFARE DIVISION

2000 NAVY PENTAGON

WASHINGTON DC 20350-2000

ATTN MR ALTWEGG

PROGRAM EXECUTIVE OFFICE

THEATER AIR DEFENSE

NATIONAL CENTER 2 8N06

2531 JEFFERSON DAVIS HIGHWAY

ARLINGTON VA 22242-5170
ATTN RADM PELAEZ

NEWPORT NEWS SHIPBUILDING INC

4101 WASHINGTON AVE

NEWPORT NEWS VA 23607

ATTN DD-21 PM (MR TOM REDDY)

PEO-DD-21 AND ASSOCIATED

TECHNOLOGIES

NATIONAL CENTER $26 S 14$

2531 JEFFERSON DAVIS HIGHWAY

ARLINGTON VA $22242-5165$

ATTN MR JOHNDROW

1 PEO (TAD) PMS410 SURFACE LAUNCHING

SYSTEMS

NATIONAL CENTER 2 7NXX

2531 JEFFERSON DAVIS HIGHWAY

ARLINGTON VA 22242-5165

ATTN SEA 09NR

(MR WILLIAM KASTNER)

3

NAVAL RESERVE PROGRAM OFFICE

NATIONAL CENTER 3

2531 JEFFERSON DAVIS HIGHWAY

ARLINGTON VA 22242-5165

ATTN SEA 03

(RADM COYLE)

(CAPT NEEDHAM)

1

1

CHIEF ENGINEER DEPUTY COMMANDER

FOR ENGINEERING

NATIONAL CENTER 3

2531 JEFFERSON DAVIS HIGHWAY

ARLINGTON VA 22242-5165

ATTN SEA 03M

(MR ALEXIS KAZNOFF)

1

NATIONAL CENTER 4

2531 JEFFERSON DAVIS HIGHWAY

ARLINGTON VA 22242-5165 


\section{DISTRIBUTION (Continued)}

Copies

ATTN SEA 03K

(MR PETERIS PRIKALS JR)

SEA 03K2

(MR DONALD CEBULSKI)

COMBAT SYSTEMS DESIGN AND

ENGINEERING GROUP

NATIONAL CENTER 2

2531 JEFFERSON DAVIS HIGHWAY

ARLINGTON VA 22242-5165

ATTN CAPT FOSKETT

COMMANDING OFFICER

NAVAL RESERVE UNIT PMS TNW 106

NAVAL AND MARINE CORPS RESERVE

CENTER

NAVAL STATION WASHINGTON BLDG 351

2701 SOUTH CAPITAL ST SW

WASHINGTON DC 20373-5812

ATTN HOWARD BOWMAN

HEAD FIRE RESEARCH OFFICE

RESEARCH AND TECHNOLOGY DIV

NAVAL AIR WARFARE CENTER

WEAPONS DIVISION

CODE 474310D

CHINA LAKE CA 93555-6001

ATTN MILTON SCATURRO

CODE 4A08

NAVAL SURFACE WARFARE CENTER

PORT HUENEME DIVISION

4363 MISSILE WAY

PORT HUENEME CA 93043-4307

ATTN IVAN CAPLAN

CODE 0115

CARDEROCK DIVISION

NAVAL SURFACE WARFARE CENTER

3A LEGGETT CIRCLE

ANNAPOLIS MD 21402

\section{NON-DOD ACTIVITIES (CONUS)}

THE CNA CORPORATION

P O BOX 16268

ALEXANDRIA VA 22302-0268
ATTN ROBERT S ROSEN

Copies

LAWRENCE LIVERMORE NATIONAL

LABORATORY

20201 CENTURY BLVD $1^{\text {ST }}$ FLOOR

GERMANTOWN MD 20874

ATTN MICHAEL E KASSNER

10

DEPARTMENT OF MECHANICAL

ENGINEERING

ROGERS HALL 414

OREGON STATE UNIVERSITY

CORVALLIS OR 97331-6001

ATTN MR SAMUEL MARSHALL LOCKHEED MARTIN CORPORATION 1725 JEFFERSON DAVIS HIGHWAY

CRYSTAL SQUARE 2 SUITE 300

ARLINGTON VA 22042-4127

ATTN MR DAVID JOHNSON MR NEIL ANDERSON MR MICHAEL SANTORO

UNITED DEFENSE LP ARMAMENT SYSTEMS DIVISION 4800 EAST RIVER ROAD MINNEAPOLIS MINNESOTA 55421

ATTN MR JOAQUIM TAVARES 1 NORTHRUP GRUMMAN CORPORATION POST OFFICE BOX 3499 MS 21-3

SUNNYVALE CA $94088-3499$

ATTN JAMES CECH

HUGHES NAVAL AND MARITIME SYS

2001 JEFFERSON DAVIS HIGHWAY

SUITE 703 CRYSTAL PLAZA 1

ARLINGTON VA 22202-3602

ATTN FRANCIS LUNSFORD

GENERAL DYNAMICS

LAND SYSTEMS DIVISION

P O BOX 2074

WARREN MI 48090-5075

ATTN AL DILLINGHAM

3030 RED HILL AVE

SANTA ANA CA 92705-5866 


\section{DISTRIBUTION (Continued)}

Copies

ATTN MICHAEL SCHERR PROGRAM EXECUTTVE OFFICE UNDERSEA WARFARE PMO 406A 2531 JEFFERSON DAVIS HWY ARLINGTON VA $22242-5169$

ATTN RICHARD FREER OCEAN SYS ENGINEERING CORP 1734 ELTON ROAD

SUITE 219

SILVER SPRING MD 20903

ATTN A ROSS COHEN ROSS COHEN ASSOCIATES 1651 S DILLON

MESA AZ 85208-4698

ATTN ROBERT STRANGE NKF ENGINEERING INC $2100 \mathrm{~S}$ WASHINGTON BLVD SUITE 2119

ARLINGTON VA 22204-5710

ATTN ALFRED WHITTLE III MARTIN MARIETTA AERO AND NAVAL SYSTEMS 103 CHESAPEAKE PARK PLAZA

BALTIMORE MD 21220

ATTN JAMES WILLIAMS LORAL VOUGHT SYSTEMS P O BOX 650003

MS WT-10

DALLAS TX 75265-0003

ATTN JOANNE BECKMAN CRUCIBLE MATERIALS CORPORATION 6003 CAMPBELLS RUN ROAD PITTSBURGH PA 15205

ATTN PAUL BANIA TITANIUM METALS CORPORATION 1999 BROADWAY DENVER CO 80202

ATTN FRANK LUCIA METALS UNLIMITED 1372 BENNETT DRIVE UNIT 100

LONGWOOD FL 32750
1

ATTN PROF WILLIAM BAESLACK COLLEGE OF ENGINEERING OHIO STATE UNIVERSITY 208 BRICKER HALL COLUMBUS OH 43210

1

ATTN WILLIAM LOVE RMI TITANIUM COMPANY 1000 WARREN AVE P O BOX 269 NILES OH 44446-0269

ATTN AARON HENNAGAN TITANIUM METALS CORPORATION PO BOX 2128

HENDERSON, NV 89015

1

\section{INTERNAL}

B60 (TECHNICAL LIBRARY) 3

G20 10

G21 (MILLS) 10

G21 (POFF) 1

G50 2

G704 (YAGLA) 10

G72 10

$\begin{array}{ll}\text { G72 (LOWRY) } & 10\end{array}$ 
